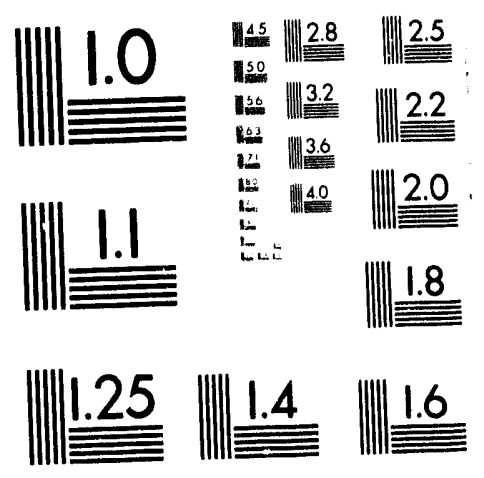



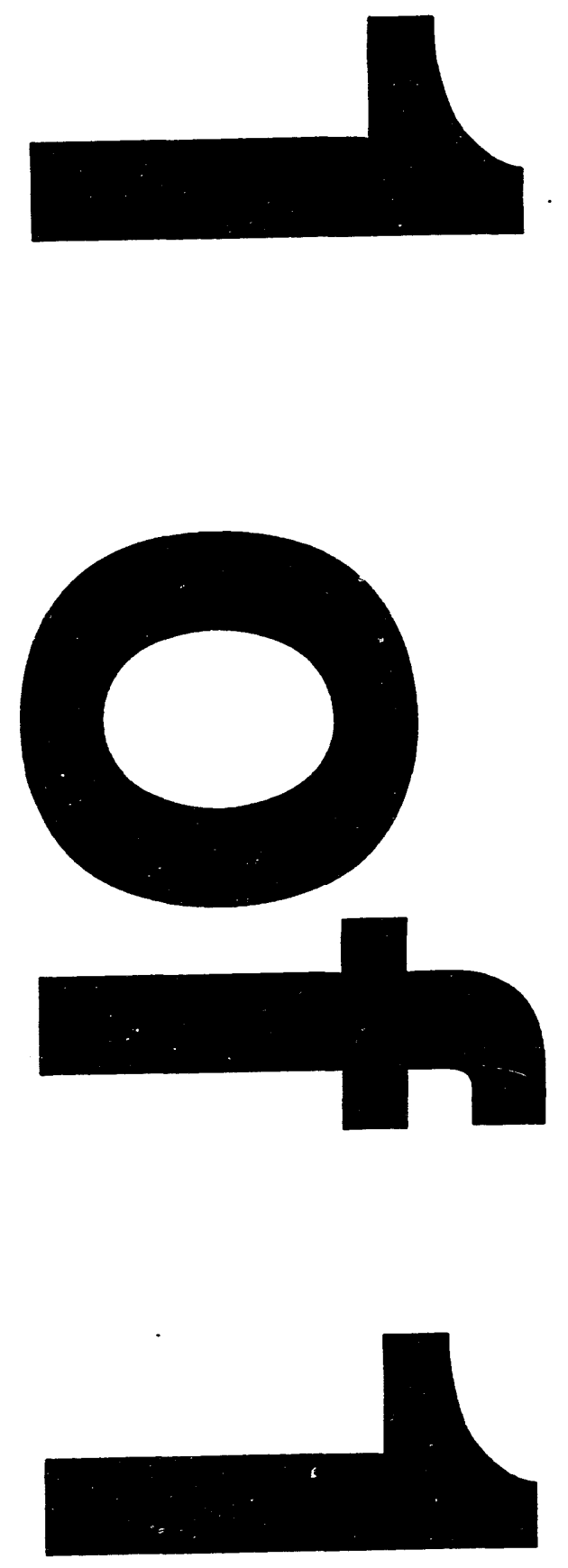


\title{
Ferrocyanide Safety Program: Heat Load and Thermal Characteristics Determination for Selected Tanks
}

\author{
J. M. McLaren \\ R. J. Cash
}

Date Published

November 1993

Prepared for the U.S. Department of Energy Office of Environmental Restoration and Waste Management

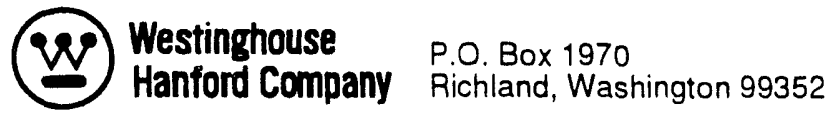

Hanford Operations and Engineering Contractor for the

U.S. Department of Energy under Contract DE-AC06-87RL10930 


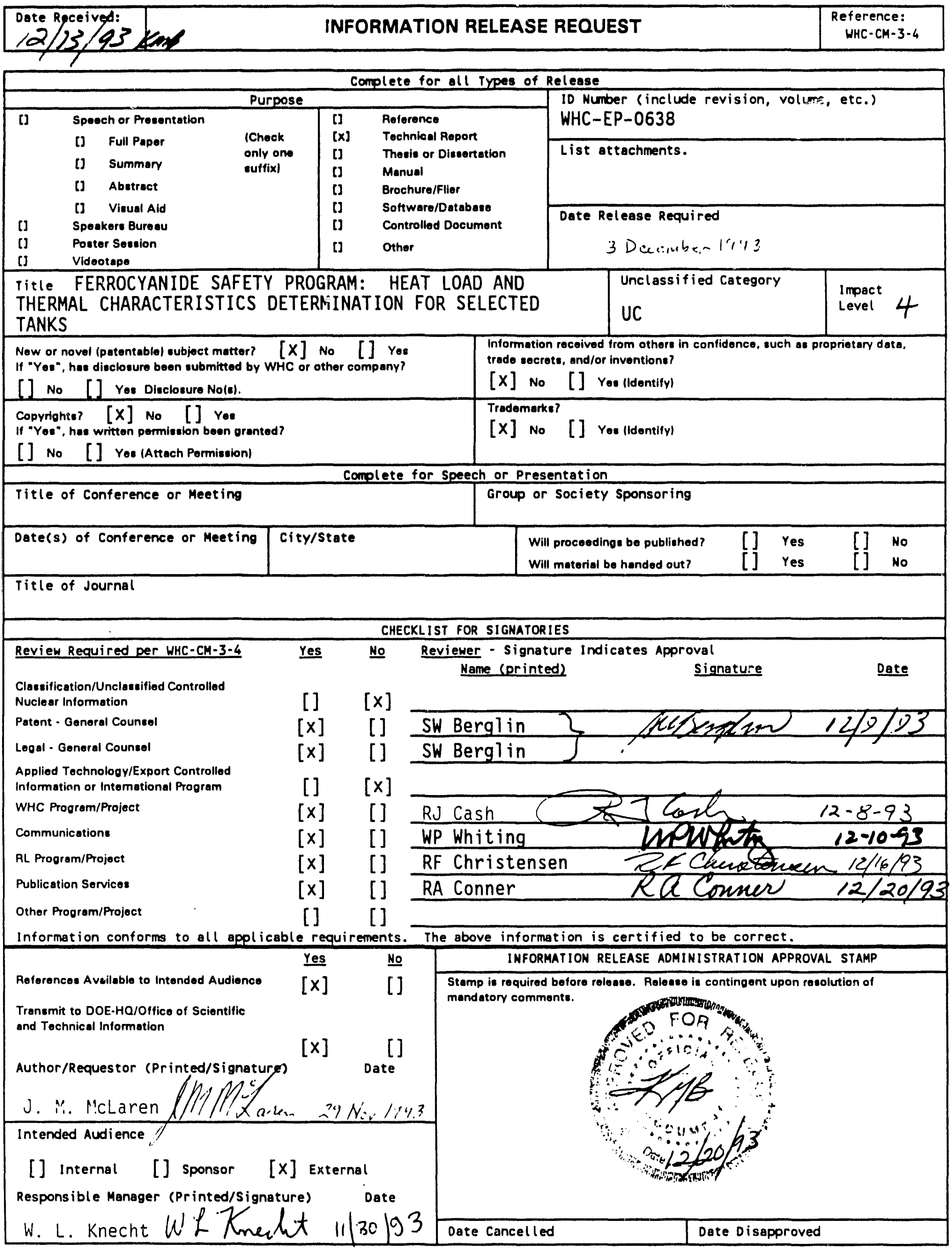




\section{EXECUTIVE SUMMARY}

An analysis was conducted to determine the heat loads, conductivities, and heat distributions of waste tanks 241-BY-105, $-106,-108,-110,-111$, and 241-C-109 at the Hanford Site. The heat distribution of tank 241-BY-111 was determined to be homogeneously distributed throughout the sludge contained in the tank. All of the other tanks, with the exception of 241-C-109, showed evidence of a heat-producing layer at the bottom of the tanks. No

evidence of a heat-producing layer in a position above the bottom was found. The thermal conductivities were determined to be within the ranges found by previous laboratory and computer analysis. The heat loads of the tanks were found to be below $2.81 \mathrm{~kW}$ (9600 Btu/hr). 


\section{CONTENTS}

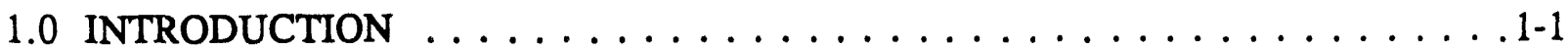

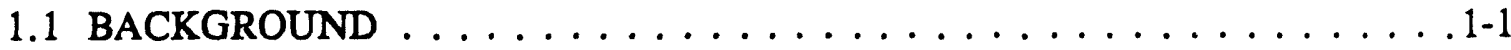

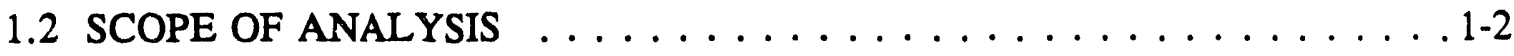

1.3 SUMMARY OF RESULTS $\ldots \ldots \ldots \ldots \ldots \ldots \ldots \ldots \ldots \ldots \ldots$

2.0 METHODOLOGY AND MODELS $\ldots \ldots \ldots \ldots \ldots \ldots \ldots \ldots \ldots \ldots$

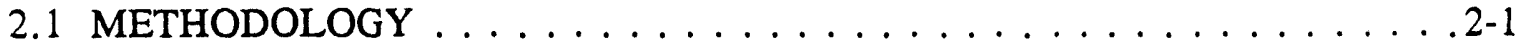

2.2 DESCRIPTION OF MODELS $\ldots \ldots \ldots \ldots \ldots \ldots \ldots \ldots \ldots \ldots$

2.2.1 DESCRIPTION OF THE TANKS $\ldots \ldots \ldots \ldots \ldots \ldots \ldots .2-1$

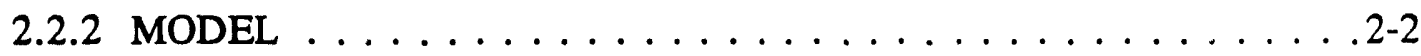

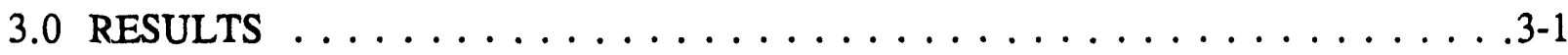

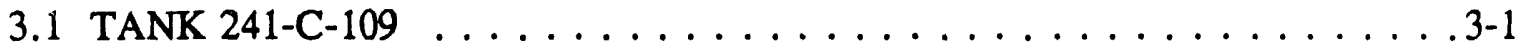

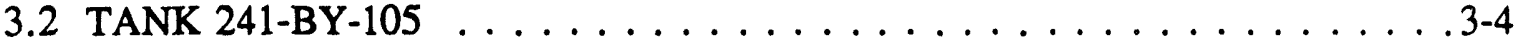

3.3 TANK $241-B Y-106 \ldots \ldots \ldots \ldots \ldots \ldots \ldots \ldots \ldots \ldots .4 \ldots \ldots \ldots$

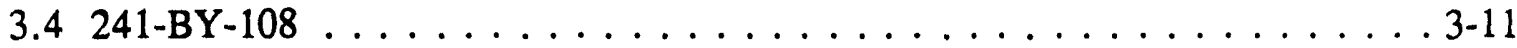

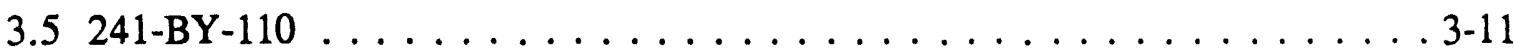

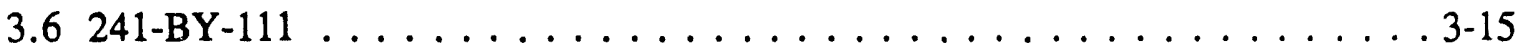

3.7 HEAT LOAD VS AIR TEMPERATURE $\ldots \ldots \ldots \ldots \ldots \ldots \ldots \ldots$

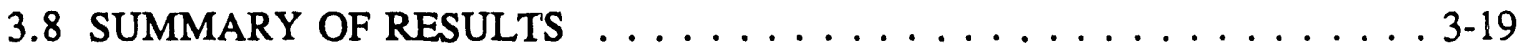

4.0 CONCLUSIONS $\ldots \ldots \ldots \ldots \ldots \ldots \ldots \ldots \ldots \ldots \ldots \ldots \ldots \ldots \ldots$

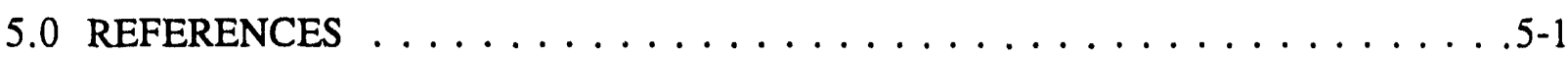
APPENDIX

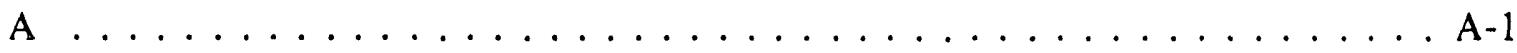




\section{WHC-EP-0638}

\section{LIST OF FIGURES}

2-1 Noding Diagram of Waste Storage Tanks, Flat Bottom Model $\ldots \ldots \ldots$ 2-3

2-2 Noding Diagram of Waste Storage Tank, Stepped Bottom Model . . . . . . . . 2-4

3-1 Tank 241-C-109 Temperature vs Height, 19 December 1991 Data . . . . . . . . 3-2

3-2 Tank 241-C-109 Temperature vs Height, Prediction vs Data . . . . . . . 3-3

3-3 Tank 241-BY-105 Temperature vs Height, 11 January 1992 Data . . . . . . . . 3-5

3-4 Tank 241-BY-105 Neutron and Gamma Scans vs Height . . . . . . . . . . . . 3-6

3-5 Tank 241-BY-105 Temperature vs Height, Prediction vs Data, Riser $1 \ldots \ldots$. . 3-7

3-6 Tank 241-BY-105 Temperature vs Height, Prediction vs Data, Riser 10C . . . 3-8

3-7 Tank 241-BY-106 Neutron and Gamma Scans vs Height, Riser 10B . . . . . . . . 3-9

3-8 Tank 241-BY-106 Temperature vs Height, 1 December 1991 Data and Estimation . . . . . . . . . . . . . . . . . . . . . . .

3-9 Tank 241-BY-106 Temperature vs Height, Prediction vs Data

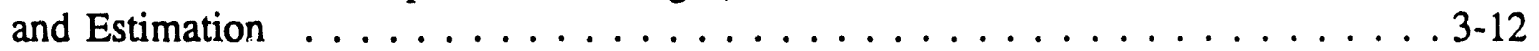

3-10 Tank 241-BY-108 Temperature vs Height, Prediction vs 29 December 1991 Data . . . . . . . . . . . . . . . . . . . . . . . 3-13

3-11 Tank 241-BY-110 Neutron and Gamma Scans vs Height, Riser $3 \ldots$. . . . . 3-14

3-12 Tank 241-BY-110 Temperature vs Height, Predictions vs 8 December 1991 Data . . . . . . . . . . . . . . . . . . . . . . . . . 3-16

3-13 Tank 241-BY-111 Data Vs Prediction . . . . . . . . . . . 3-17

3-14 Heat Load vs Temperature . . . . . . . . . . . . . . . . . 3-18 
WHC-EP-0638

\section{LIST OF TABLES}

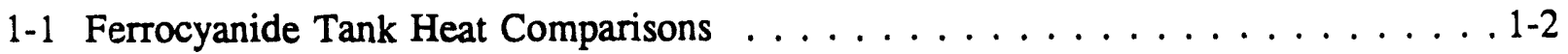

3-1 Summary of Results. . . . . . . . . . . . . . . . . . . 3-19

3-2 Corrected Values for Heat Loads . . . . . . . . . . . . . . . . . . 3-19 


\section{HEAT LOAD AND THERMAL CHARACTERISTICS DETERMINATION FOR SELECTED FERROCYANIDE TANKS}

\subsection{INTRODUCTION}

The radioactive waste storage tanks at the Hanford Site have been used since the 1940s. Recently, much attention has been focused upon these tanks as a result of problems that have occurred with or been envisioned for them. Some of these problems have been identified for some time but, for various reasons, have remained unresolved; others have been identified only recently. One of the problems is the potential interaction of ferrocyanide with nitrates in the presence of high temperatures, a condition that has been postulated for some of the tanks (Burger 1989; Burger and Scheele 1988). As a result, it was considered advisable to determine the heat load of these tanks.

The heat loads of the ferrocyanide-bearing tanks were determined in the 1970s, using psychrometric data. A thermal analysis of tank 241-BY-104 using the HEATING7 code determined that the heat load of this tank was markedly less than the published value of $4.98 \mathrm{~kW}(17000 \mathrm{Btu} / \mathrm{hr}$ ) (Hanlon 1991). A subsequent analysis of the airflow in the tank from the atmosphere due to in-leakage through the piping that penetrates the tank showed a very low heat loss due to airflow and evaporation. The resulting heat load of tank $241-\mathrm{BY}-104$ was determined to be $1.47 \mathrm{~kW}(5000 \mathrm{Btu} / \mathrm{hr})$. As a result of the re-evaluation of this tank, a request was initiated to use thermal analysis in order to determine the heat loads for the following tanks: 241-BY-105, -106, -108, -110, -111, and 241-C-109.

The objectives of this analysis are as follows:

a. Determine the heat loads of the selected tanks.

b. Determine the thermal conductivities of the contents of these selected tanks.

c. Determine the heat distribution within the selected tanks.

\subsection{BACKGROUND}

The published values of the heat loads in the ferrocyanide-bearing tanks vary greatly (Hanlon 1991). They do not show consistency in relation to their contents, nor with respect to one another. These heat loads were determined by using psychrometric analysis of the inlet and outlet airflow conditions in the 1970s. These results for the individual tanks vary. widely; for example, in the case of $241-\mathrm{BY}-104$, from $2.9 \mathrm{~kW}(7800 \mathrm{Btu} / \mathrm{hr})$ to $11.43 \mathrm{~kW}$ $(39000 \mathrm{Btu} / \mathrm{hr})$. This variation is due in part to the use of individual discrete points to evaluate the tank heat load, as opposed to using an integrated data scheme. It should be pointed out that such a scheme was not considered necessary at the time the readings were 
made. The difficulty of using discrete points is that the outlet conditions of the airflow from a tank are very dependent on the inlet conditions of several previous days. If the time of the readings was preceded by a period of cool, damp conditions, the outlet conditions will be totally different than those preceded by a period of warm, dry conditions, even though the inlet conditions at the time of the readings are the same in either case. Additionally, the psychrometric data acquired in the 1970s were evaluated during a time when the tanks were on forced ventilation and had not yet been stabilized. At present, forced ventilation is not being used on many of the tanks, and several have been saltwell pumped, removing as much pumpable liquid as possible from them. As the liquid contained some of the heat-generating radionuclides, the stabilization reduced the heat loads of the stabilized tanks. As a result, the actual values of the heat loads of these tanks may be very different from the values determined previously (Hanlon 1991). The previous estimated heat loads of some of the tanks show wide variations for similar conditions, as shown in Table 1-1.

Table 1-1. Ferrocyanide Tank Heat Comparisons.

\begin{tabular}{|c|c|c|c|}
\hline Tank & Sludge level (in.) & $\begin{array}{c}\text { Max temp } \\
\left({ }^{\circ} \mathrm{F}\right)\end{array}$ & $\begin{array}{c}\text { Heat load listed } \\
(\mathrm{Btu} / \mathrm{hr})\end{array}$ \\
\hline BY-106 & 241 & 131 & 12200 \\
\hline BY-105 & 190 & 122 & 37700 \\
\hline BY-111 & 174 & 86 & 34200 \\
\hline BY-104 & 155 & 129 & 17000 \\
\hline BY-103 & 153 & 82 & 8600 \\
\hline BY-110 & 152 & 122 & 25200 \\
\hline BY-101 & 148 & 76 & 8200 \\
\hline
\end{tabular}

\subsection{SCOPE OF ANALYSIS}

This report will cover the analysis of tanks 241-BY-105, -106, -108, -110, -111, and 241-C-109. The analysis will determine (1) the heat loads of these tanks; (2) the thermal conductivity of the contents of these tanks; and (3) the distribution of the heat generation within these tanks. This analysis will not consider the effect of air infiltration into the tank from various piping systems, as this infiltration has been previously determined to have little effect. The imposed boundary conditions will be an atmospheric temperature of $12.2^{\circ} \mathrm{C}$ $\left(54^{\circ} \mathrm{F}\right)$ at the surface of the soil cover over the tanks, and a temperature of $12.8^{\circ} \mathrm{C}\left(55^{\circ} \mathrm{F}\right)$ at the water table, which is assumed to be at a depth of $61 \mathrm{~m}(200 \mathrm{ft})$ below the surface of the soil. The analysis will not attempt to determine horizontal distribution of the heat source. 


\subsection{SUMMARY OF RESULTS}

The analysis determined that the values of the conductivities of the waste in the tanks were within the values previously determined by computer analysis and within those values determined by laboratory analysis. The heat loads were determined to be less than $1.76 \mathrm{~kW}$ $(6000 \mathrm{Btu} / \mathrm{hr})$. Tank 241-BY-111 showed a homogeneous heat distribution throughout the sludge, while the other tanks showed some degree of concentration at the bottom of the tanks. Tank 241-C-109 did not have enough data to allow for full analysis; only the heat load and a very approximate conductivity could be determined.

Subsequent to this analysis, the method and models used in analyzing the heat loads of the single-shell waste storage tanks were refined. As a result of this refinement, a factor of 1.6 was determined to be applied to the results of this analysis to provide a more accurate indication of the tank heat loads. The values given in this report are nominal values, with a band of uncertainty of \pm 38 percent. As a result, the heat loads of the tanks analyzed in this report are considered less than $2.81 \mathrm{~kW}(9600 \mathrm{Btu} / \mathrm{hr})$. 
This page intentionally left blank. 


\subsection{METHODOLOGY AND MODELS}

\subsection{METHODOLOGY}

The approach used for the analyses of the selected tanks analyzed in this report was to utilize a heat transfer code to determine the heat flow and temperatures in the tanks. The approach required that a two-dimensional model of each tank be created to (1) determine the heat load of the tank; and (2) develop the thermal characteristics of tank contents by being compared against known data.

The computer code used to determine the heat load, thermal characteristics of the waste, and heat generation distribution was HEATING7 (Allen 1992). The HEATING7 code is a heat transfer analysis code used to determine steady-state and transient temperature distributions within a described structure. The code uses heat conduction, convection, radiative heat transfer parameters, and iterative solution techniques on a model of the structure to solve for the temperatures at nodes described by the model. The code does not have the capability to determine flow patterns due to convective heat transfer, or the temperature distribution in the convecting region. Instead, convective heat transfer is calculated via standard empirical correlations. HEATING7 uses an improved iterative solution technique for steady state solutions compared to previous versions, and also has a graphical interface. In this analysis, various conductivities and heat source distributions were used in a model of each of the selected tanks with the HEATING7 code to determine the heat load and thermal conductivities of the waste in the tanks. The calculated results were compared with the temperature data taken from each tank.

\subsection{DESCRIPTION OF MODELS}

This section describes the single-shell waste storage tanks and the models used to analyze each tank. The section is organized into two parts. The first section describes each waste tank and its contents. The second section describes the two-dimensional model used to determine the heat load and thermal conductivities of the waste in the tank. These models assume that the outside air temperature is $12.2^{\circ} \mathrm{C}\left(54^{\circ} \mathrm{F}\right)$; the water table is located $61 \mathrm{~m}$ $(200 \mathrm{ft})$ below the surface; and its temperature is $12.8^{\circ} \mathrm{C}\left(55^{\circ} \mathrm{F}\right)$.

\subsubsection{DESCRIPTION OF THE TANKS}

The selected tanks are all single-shell waste storage tanks. Five are located in the BY tank farm, with one in the $\mathrm{C}$ tank farm. These are all cylindrical concrete tanks with a domed concrete top. The tanks are set on a concrete slab that is dished so that the center is approximately $1 \mathrm{ft}$ below the edges. The tanks are $22.9 \mathrm{~m} \mathrm{(75} \mathrm{ft)} \mathrm{in} \mathrm{diameter.} \mathrm{The} \mathrm{tanks}$

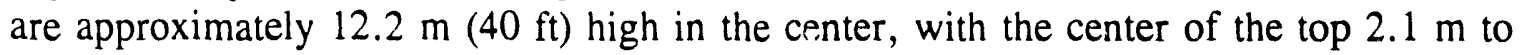
$2.7 \mathrm{~m} \mathrm{(7} \mathrm{to} 9 \mathrm{ft}$ ) below the surface of the soil. They have a steel liner, made of plates 
welded together, that covers the bottom and sides of the tank up to the wall-dome intersection. There are numerous piping penetrations in the top of the tank as well as in the sides. The tanks were periodically filled with a slurry of radioactive waste forms that were allowed to settle out. During this periodic filling process the excess liquid was removed after it reached a certain level. This process was repeated several times. After this process was completed, another waste addition of evaporator concentrates that were saturated at boiling temperature was made to some of the tanks. As the solution cooled, this waste precipitated out as crystals on top of the waste that was already in place. As a result, in some of the tanks there are two layers of different waste in the tank. The crystalline layer is the "crust" or "saltcake," and the lower layer is the "sludge." Some of the tanks were stabilized by pumping out all the liquid possible. There is no liquid on the surface of any of the selected tanks, and there is varying dampness in the sludge region.

\subsubsection{MODEL}

The models used for the HEATING7 code were two dimensional models. Parameters developed from a previous analysis were used as starting points for the analyses (McLaren 1991). Each model of an analyzed tank is unique to that tank, because of the depth of soil over the tank and the amount of sludge within the tank. The model consists of regions, connected together by boundaries, with the appropriate heat transfer conditions describing these boundaries and regions. The heat sources are described by tabular functions, and can represent a uniform or non-uniform distribution.

Because of the different depths of sludge in the tanks and the different locations of the temperature measuring equipment, two different models for the HEATING7 code were developed to describe the tanks. Both models showed the tanks to have a stepped top (to describe the shape of the dome in cylindrical coordinates) and either a flat bottom, or a stepped bottom, depending upon the location of the thermocouple tree and the depth of the sludge in the tank. These models were made up of 22 to 26 regions and four boundary conditions. Nine regions described the soil over the tank, around the tank, and under the tank. Three or four regions described the concrete bottom and sides of the tank, depending upon whether the tank model was stepped or not. The concrete tank top was not separately modeled. Its volume was included in the dirt top cover. This was conservative in that the dirt has a lower thermal conductivity than the concrete. Seven regions described the air space in the tank. One region described the crust of the waste in the tank, and two to four regions described the sludge under the crust. The noding diagrams of these models are shown as Figures 2-1 and 2-2.

One of the boundary conditions was a surface of constant temperature, describing the temperature of the soil at the water table, which was considered to be $12.8^{\circ} \mathrm{C}\left(55^{\circ} \mathrm{F}\right)$ at $61 \mathrm{~m}(200 \mathrm{ft})$ below the surface. The second boundary was a surface-to-boundary condition, with forced convection heat transfer to a boundary of constant temperature, which described the soil-to-atmospheric air interface. The forced convection heat transfer was used to account for the wind that is common throughout most of the year in the tank farm areas. 
Figure 2-1. Noding Diagram of Waste Storage Tanks, Flat Bottom Model.

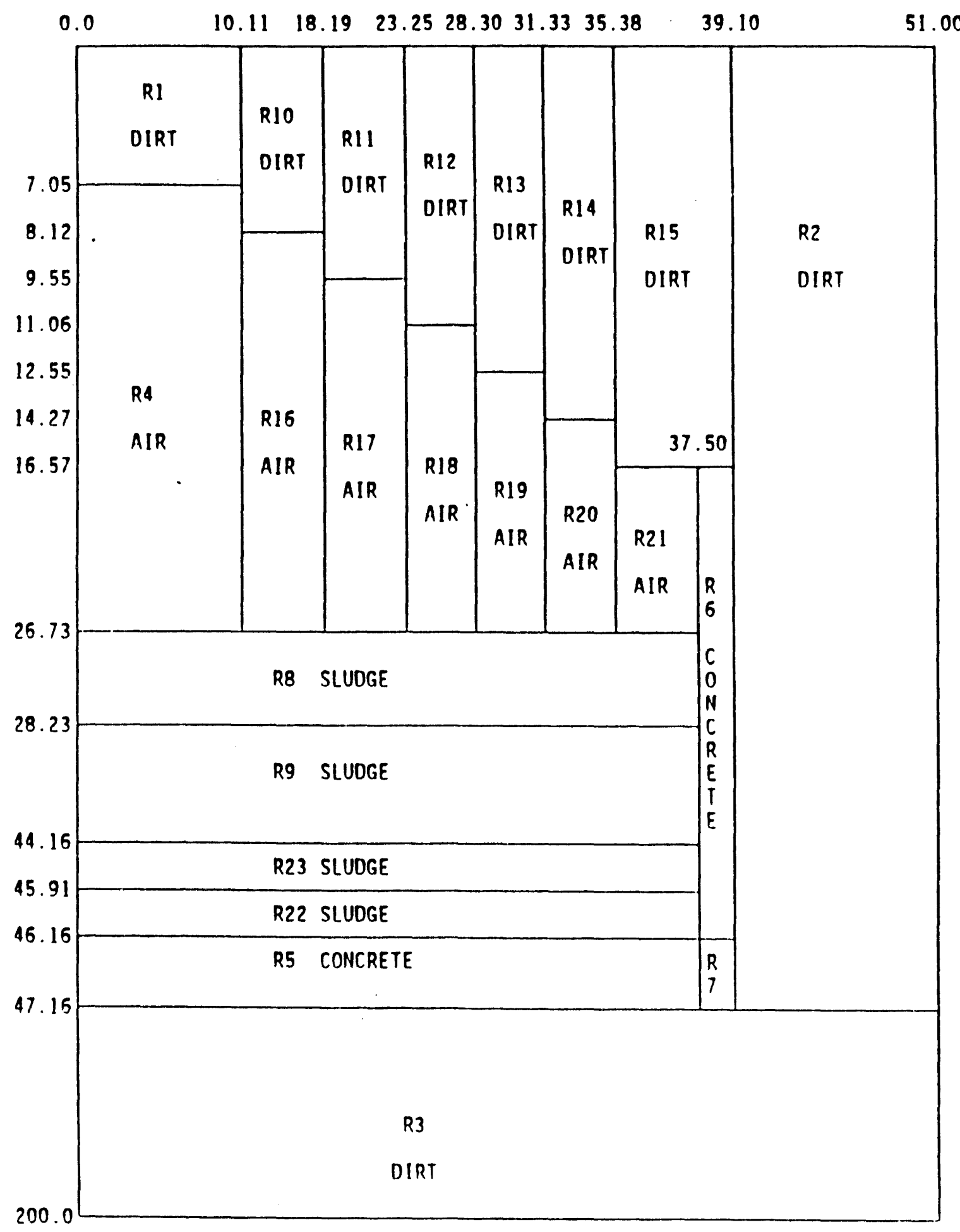


Figure 2-2. Noding Diagram of Waste Storage Tank, Stepped Bottom Model.

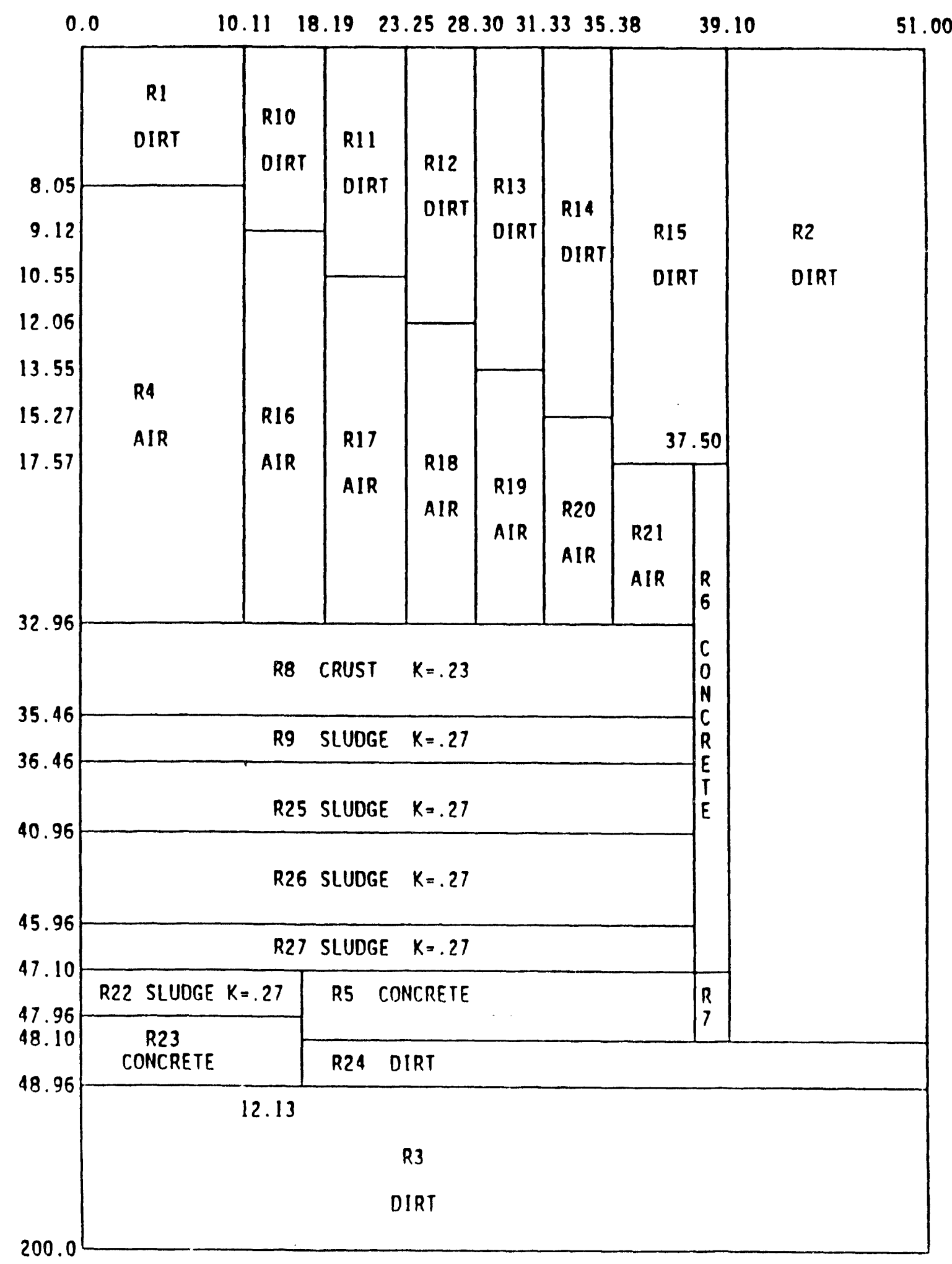


The third boundary condition is a surface-to-surface condition with convective and radiative heat transfer coefficients. This boundary condition describes the interface between the waste surface and the air space in the tank and between the air space and the tank top. The fourth boundary condition is a surface to insulator (i.e., a reflection), and is used to describe the boundary in the soil between one tank and another.

The thermal conductivity used for the concrete sides and bottom of the tank was $.0093 \mathrm{w} / \mathrm{cm}-{ }^{\circ} \mathrm{C}\left(.54 \mathrm{Btu} / \mathrm{hr}-\mathrm{ft}-{ }^{\circ} \mathrm{F}\right)$. The conductivity of the soil used was $.0043 \mathrm{w} / \mathrm{cm}-{ }^{\circ} \mathrm{C}$ $\left(.25 \mathrm{Btu} / \mathrm{hr}-\mathrm{ft}-{ }^{\circ} \mathrm{F}\right)$. These values were used in the previous analysis (McLaren 1991), and the soil value was verified by data from laboratory samples (Bouse 1975).

A detailed description of the analysis technique is provided in Appendix A. 
This page intentionally left blank. 


\subsection{RESULTS}

The following section describes the results of the analysis of the tanks. Each tank is described in turn, along with the results of the analysis. A summary of the results is given in Table 3-1. In the description of these results the terms "wet," "damp," and "dry" are used to differentiate between layers of various conductivities. These terms do not mean that the waste is in fact wet or dry.

\subsection{TANK 241-C-109}

The previously published heat load for this tank was $2.93 \mathrm{~kW}(10000 \mathrm{Btu} / \mathrm{hr})$ (Cash et al. 1992). The thermocouple tree for tank 109-C is located in riser R-8. This riser is located at a radius of $10.2 \mathrm{~m}(33.5 \mathrm{ft})$ from the centerline of the tank. At this radius, the height of the tank and the depth of the overburden are very different from the center of the tank. It was because of this that the models were developed with a stepped dome, in order to include the effects of the thickness of soil over the tank at the point of the temperature measurement. Tank $109-\mathrm{C}$ is listed as having 66,000 gallons of waste, with no crustal layer (Cash et al. 1992). This calculates to an average depth of $2 \mathrm{ft}$ in the tank. The thermocouples are $2 \mathrm{ft}$ apart, starting $4 \mathrm{in}$. above the bottom of the tank. Because of the dished bottom of the tank, the model used with a flat bottom causes the position of the bottom thermocouple to be 2.3 in. lowisr in the model than in the tank. This error was considered acceptable.

The depth of the sludge in the tank caused a problem with the analysis. There are six thermocouples in the tree, spaced at 2-ft intervals, but only one of them is actually in the sludge. The temperature readings of December 19, 1991, were used (see Figure 3-1). These readings show that the temperature for the sludge was $26.7^{\circ} \mathrm{C}\left(80^{\circ} \mathrm{F}\right)$ and the temperature for the airspace was $25.6^{\circ} \mathrm{C}\left(78^{\circ} \mathrm{F}\right)$. A parametric study was conducted by varying the heat load of the tank and the conductivity of the wastes. With no data in the sludge except for one temperature reading, no attempt was made to vary the thermal conductivity with depth in the sludge. The result of the parameter study indicated that the most probable heat load of the tank was $1.03 \mathrm{~kW}(3500 \mathrm{Btu} / \mathrm{hr})$, and the most probable conductivity of the tank was $.0047 \mathrm{w} / \mathrm{cm}-{ }^{\circ} \mathrm{C}\left(.27 \mathrm{Btu} / \mathrm{hr}-\mathrm{ft}-{ }^{\circ} \mathrm{F}\right)$. These results are shown in Figure 3-2. These numbers are reasonable, since the tank is still considered fairly wet and has not been stabilized to date. Yet the liquid level is shown as below the level of the sludge. With only one temperature reading in the sludge, the uncertainty is rather wide, but the parameter study shows that the heat load is within .97 to $1.11 \mathrm{~kW}$ (3300 to $3800 \mathrm{Btu} / \mathrm{hr}$ ), with the best fit at $1.03 \mathrm{~kW}$. 
Figure 3-1. Tank 241-C-109 Temperature vs Height, 19 December 1991 Data.

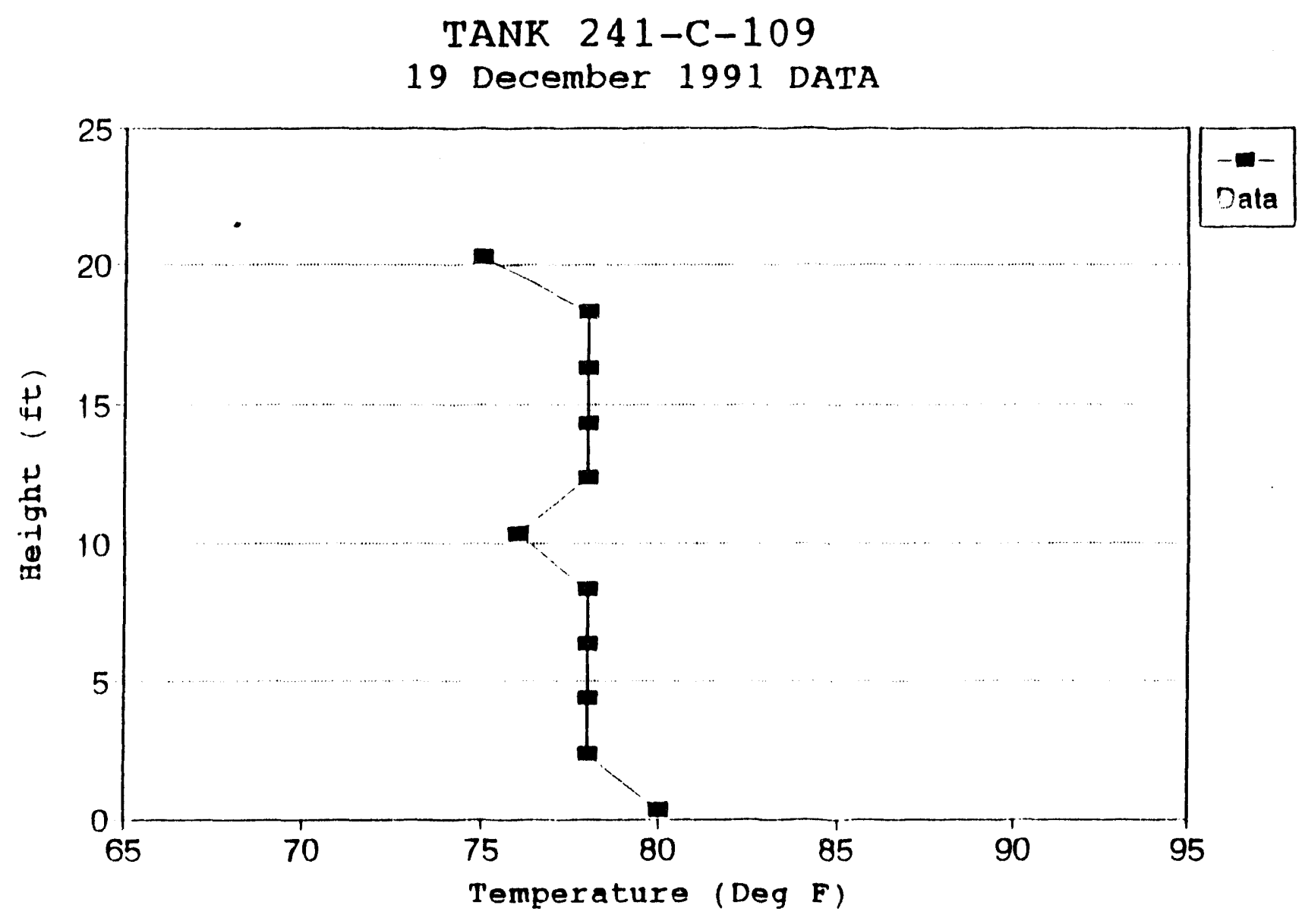




\section{WHC-EP-0638}

Figure 3-2. Tank 241-C-109 Temperature vs Height, Prediction vs Data.

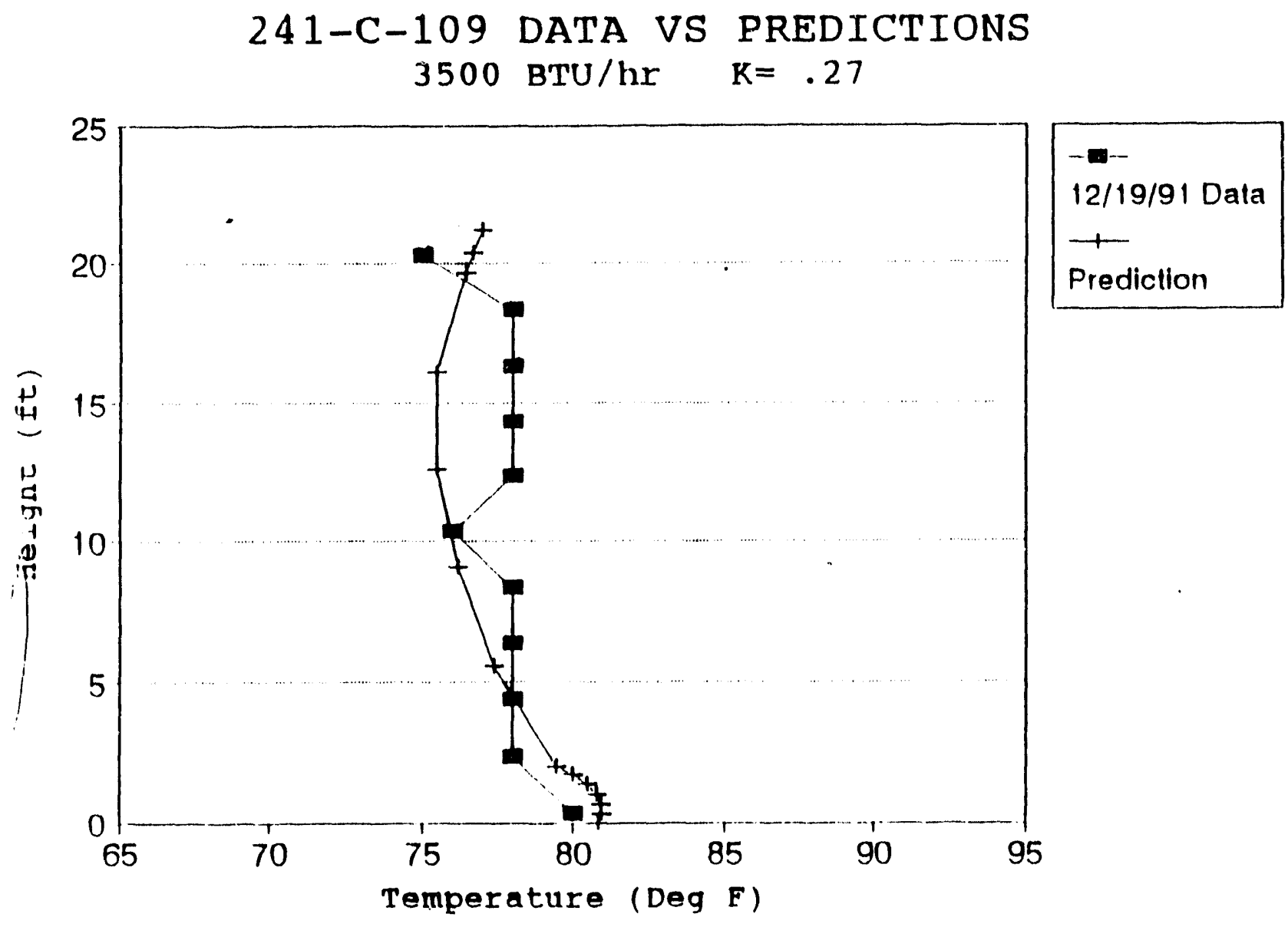




\subsection{TANK 241-BY-105}

The previously published heat load for this tank was $11.05 \mathrm{~kW}(37700 \mathrm{Btu} / \mathrm{hr})$ (Cash et al. 1992). This tank contains two thermocouple trees, located in risers R-1 and $\mathrm{R}-10 \mathrm{C}$. $\mathrm{R}-1$ is located $2.4 \mathrm{~m}(7.9 \mathrm{ft})$ from the center, and $\mathrm{R}-10 \mathrm{C}$ is located at a radius of $6.1 \mathrm{~m}(20.0 \mathrm{ft})$ and $90^{\circ} \mathrm{F}$ clockwise from R-1. The liquid observation well (LOW) used for the gamma scans is located in riser R-10B at $6.63 \mathrm{~m}(21.75 \mathrm{ft})$ from the center. The temperature data used is the January 11, 1992, data and is shown in Figure 3-3. The gamma scans in Figure 3-4 show that there is considerable variation in the activity with depth. The

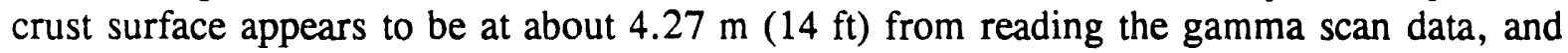
about $.76 \mathrm{~m}(21 / 2 \mathrm{ft})$ thick. Because of the variation in the depth of the sludge at the two thermocouple trees due to the dished tank bottom, a two-stepped tank bottom model was used, as shown in Figure 2-2.

A parameter study of the heat distribution was conducted. It was found that any heat distribution that did not put the bulk of the heat generation at or near the bottom of the tank produced a curve of temperature vs height that did not match the two data curves at all (see Appendix A). This is to be expected, due to the nearly constant slope of the temperature vs height data curve, as shown in Figure 3-3, which is indicative of a pure conduction problem. Attempts were made to distribute the heat in accordance with the gamma scan profile, but the resulting curves aid not match the shape of the data at all. The results of the analysis indicate that the heat load in this tank is $4000 \mathrm{Btu} / \mathrm{hr}$, with a conductivity of the sludge of $.0047 \mathrm{w} / \mathrm{cm}^{-}{ }^{\circ} \mathrm{C}\left(.27 \mathrm{Btu} / \mathrm{hr}-\mathrm{ft}-{ }^{\circ} \mathrm{F}\right)$, and of the saltcake of $.0040 \mathrm{w} / \mathrm{cm}-{ }^{\circ} \mathrm{C}\left(.23 \mathrm{Btu} / \mathrm{hr}-\mathrm{ft}-{ }^{\circ} \mathrm{F}\right)$. The plots of the predicted temperature vs height curves from the model vs the data for the two data traces are shown in Figure 3-5 for R-1 and Figure 3-6 for R-10C.

\subsection{TANK 241-BY-106}

The previously published heat load for this tank was $3.58 \mathrm{~kW}(12200 \mathrm{Btu} / \mathrm{hr})$ (Cash et al. 1992). The thermocouple tree in this tank is located in riser R-1, which is $2.44 \mathrm{~m}(8 \mathrm{ft})$ from the center of the tank. The data used for the analysis were the December 1,1991 , readings. The temperature readings for this tank are in the first $2.44 \mathrm{~m}(8 \mathrm{ft})$, with one temperature reading in the airspace. Gamma/neutron scans were taken in riser R-10B (Figure 3-7). The tank contains $5.94 \mathrm{~m}(19.5 \mathrm{ft})$ of sludge. The lack of data from 2.44 to $5.94 \mathrm{~m}$ is a handicap to the analysis. The temperature data seems to indicate that there is a possibility of heat generation above the bottom, with a layer of higher heat generation on the bottom. The model used for the analysis of this tank was the flat-bottomed model, as shown in Figure 2-1. This model was used to ease the analysis using a layer on the bottom. The loss of detail was considered acceptable due to the depth of sludge and lack of temperature information above $2.44 \mathrm{~m}$ from the bottom. Using the gamma scan data, a curve of temperature vs depth was generated that included an estimation of the temperatures from $2.44 \mathrm{~m}$ above the bottom to the surface, as shown in Figure 3-8. 
Figure 3-3. Tank 241-BY-105 Temperature vs Height, 11 January 1992 Data.

TANK 241-BY-105

11 January 1992 DATA

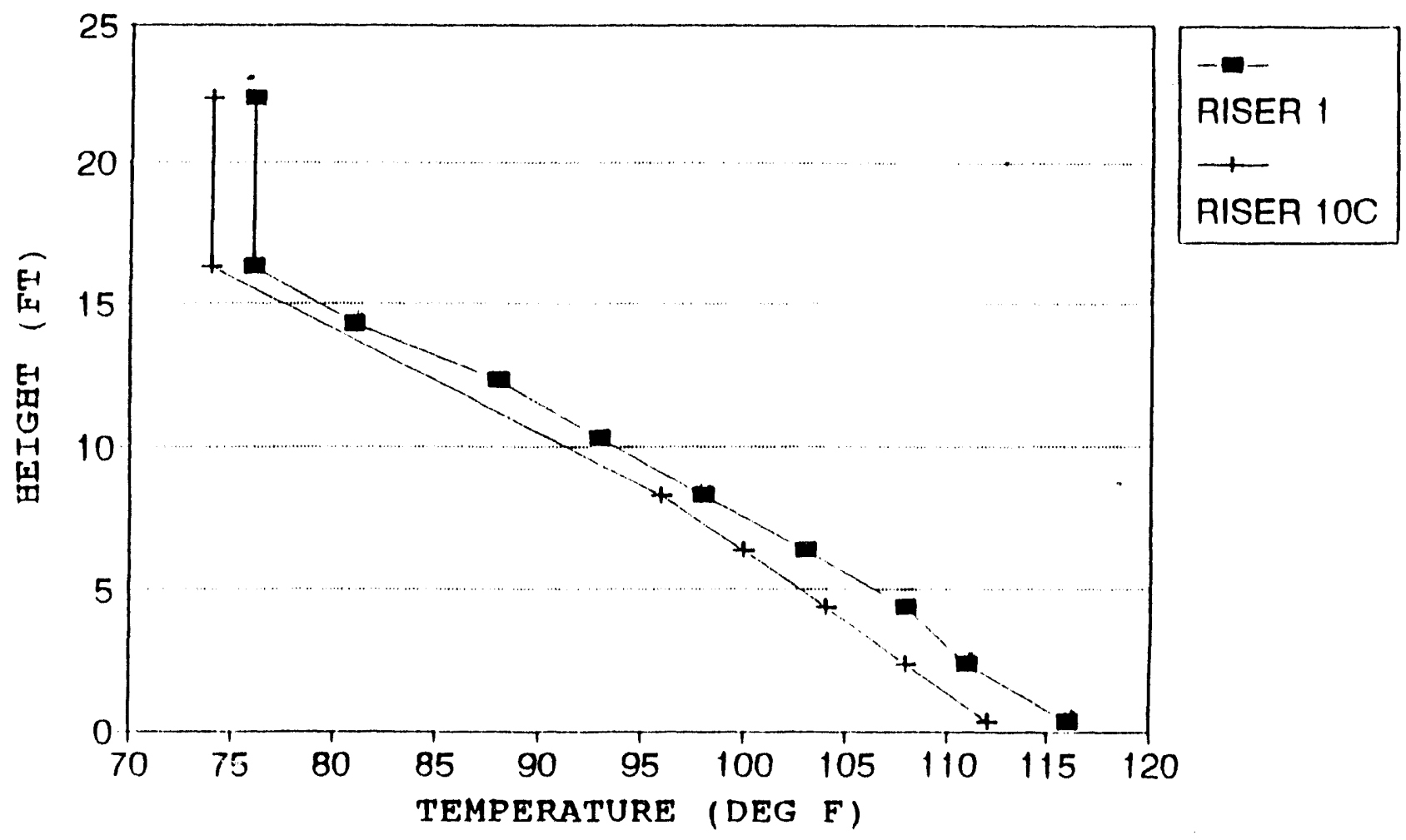


Figure 3-4. Tank 241-BY-105 Neutron and Gamma Scans vs Height.

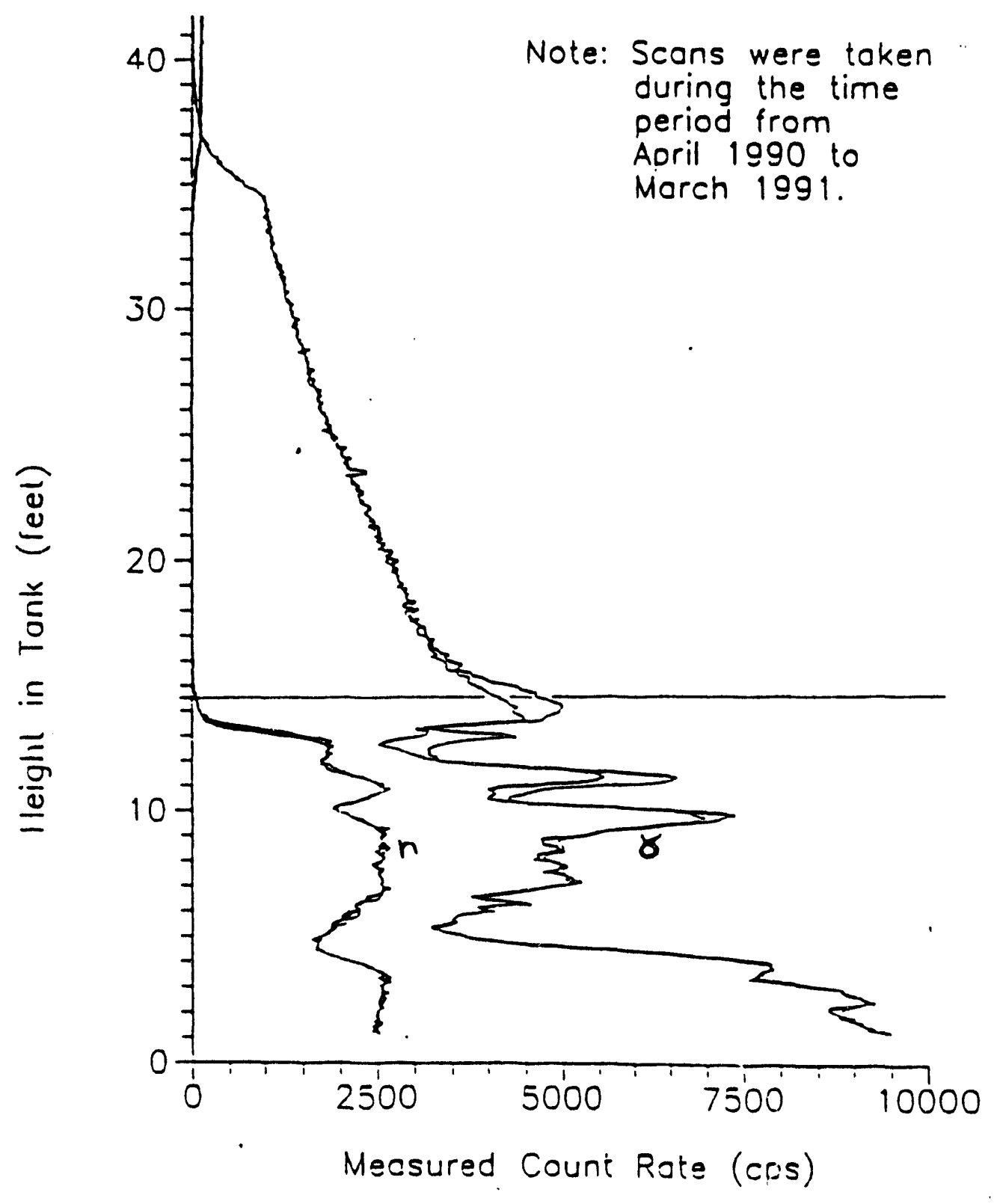


Figure 3-5. Tank 241-BY-105 Temperature vs Height, Prediction vs Data, Riser 1.

TANK 241-BY-105

RISER 1 DATA VS PREDICTIONS

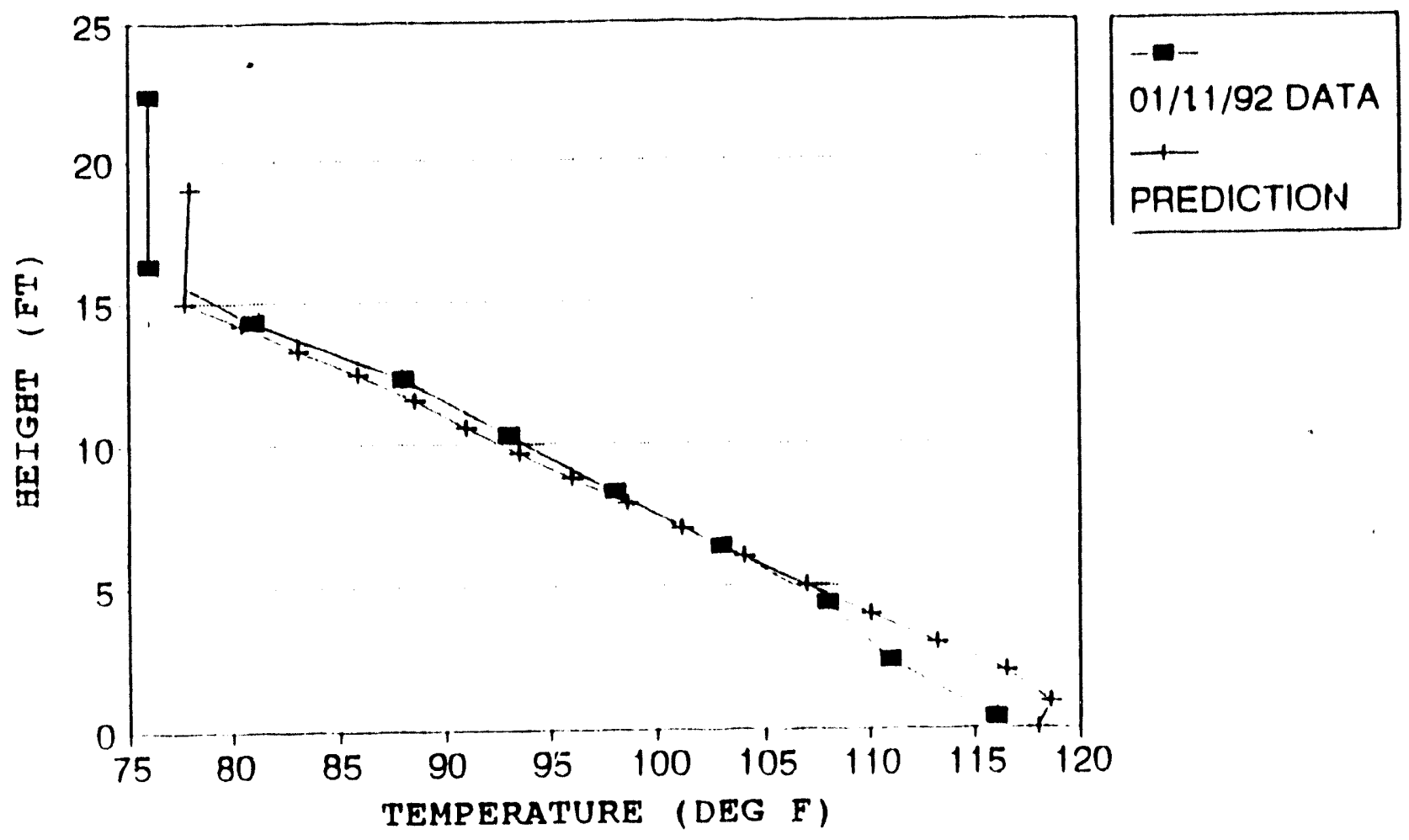


Figure 3-6. Tank 241-BY-105 Temperature vs Height, Prediction vs Data, Riser 10C.

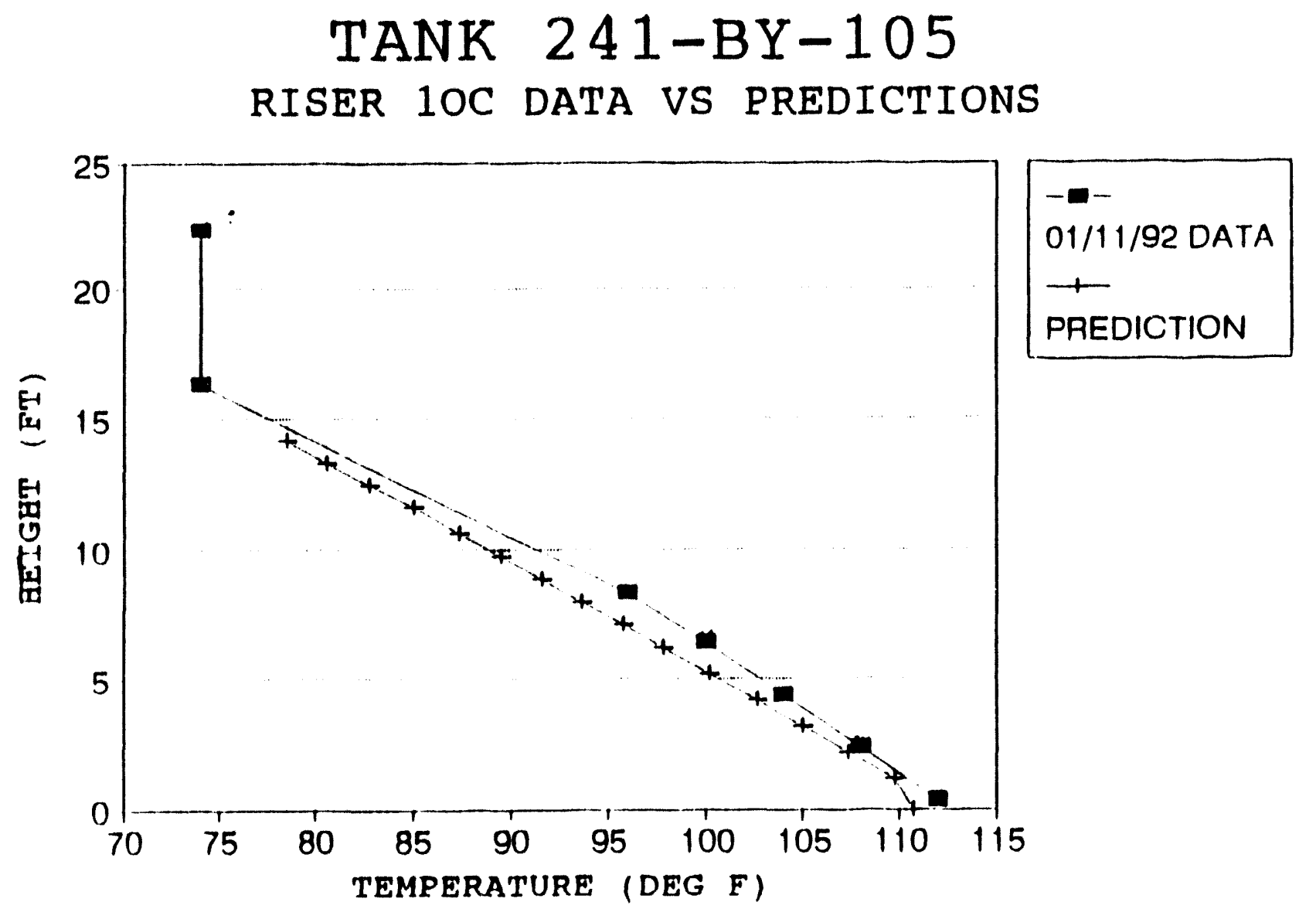


Figure 3-7. Tank 241-BY-106 Neutron and Gamma Scans vs Height, Riser 10B.

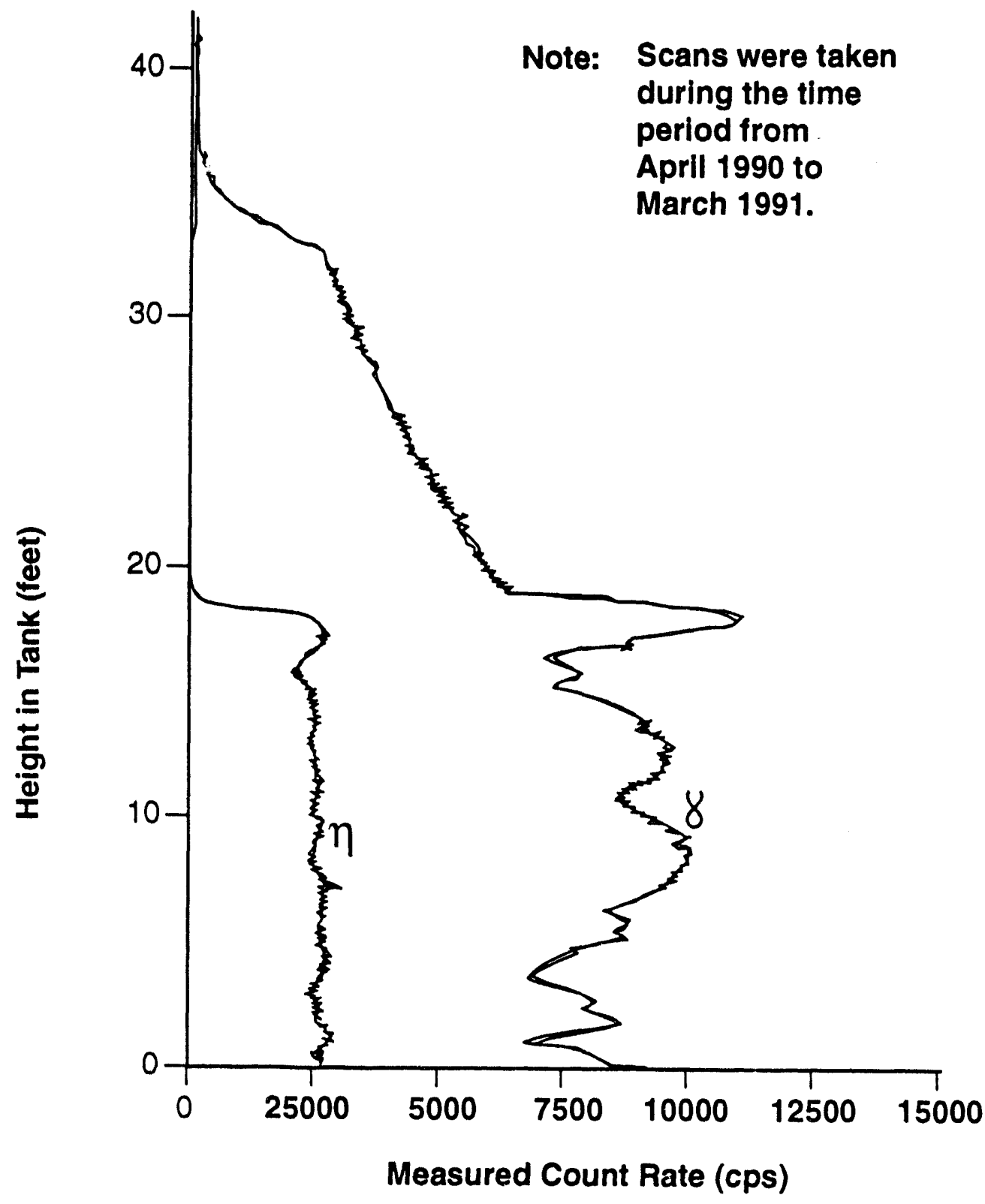


Figure 3-8. Tank 241-BY-106 Temperature vs Height, 1 December 1991 Data and Estimation.

\section{TANK 241-BY-106}

1 Dec 1991 Data and Estimation

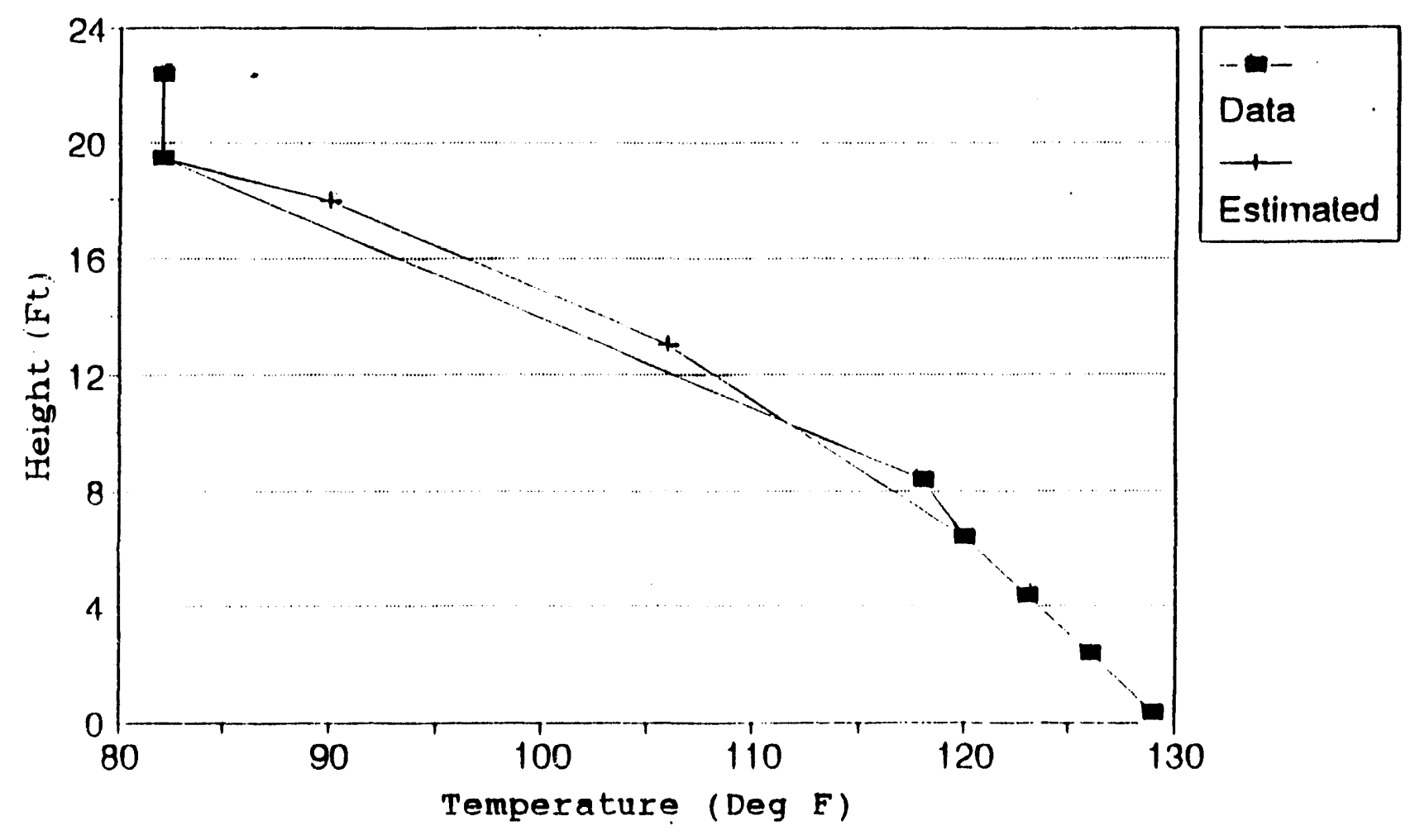


A parameter study was conducted to determine the heat distribution in the tank, as well as the heat load and the thermal conductivities. The bottom readings of the gamma scans, as shown in Figure 3-7, indicated that there could be a spike in the gamma readings below the lowest data provided. Utilizing this information, and observing the shape of the temperature vs height curve, a judgement was made to use a $7.62 \mathrm{~cm}(3 \mathrm{in}$.$) layer of higher heat$ generation and vary the heat generation in the rest of the sludge. The best fit to the data and the estimated curve was with a heat generation rate of $1.61 \mathrm{~kW}(5500 \mathrm{Btu} / \mathrm{hr})$, with $1 / 2$ the heat in the bottom $7.62 \mathrm{~cm}$ and the rest of the heat uniformly distributed in the rest of the sludge, excepting the $.46-\mathrm{m}(1-1 / 2-\mathrm{ft})$ saltcake layer on the top of the sludge. The conductivities were $.0028 \mathrm{w} / \mathrm{cm}-{ }^{\circ} \mathrm{C}\left(.16 \mathrm{Btu} / \mathrm{hr}-\mathrm{ft}-{ }^{\circ} \mathrm{F}\right)$ in the saltcake, and $.0047 \mathrm{w} / \mathrm{cm}-{ }^{\circ} \mathrm{C}$ $\left(.27 \mathrm{Btu} / \mathrm{hr}-\mathrm{ft}-{ }^{\circ} \mathrm{F}\right)$ in the sludge. The plot of the results of these parameters entered into the model and compared with the data and estimated curve is shown on Figure 3-9.

\subsection{1-BY-108}

The previously published heat load for this tank was $6.74 \mathrm{~kW}(23000 \mathrm{Btu} / \mathrm{hr})$ (Cash et al 1992). This tank has a comparatively small amount of sludge in it. From the volume data provided, the depth is calculated to be $2.13 \mathrm{~m}(7 \mathrm{ft})$. The thermocouple tree is

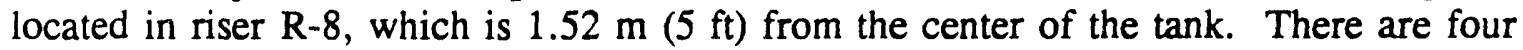
thermocoufles in the sludge, at 2-ft intervals, and six in the airspace. The data used for the analysis were the December 29, 1991, readings. There were no gamma scan data available for the analysis. An interesting point about the readings in the airspace is that they are all equal, indicating that previous work predicting isothermal conditions in the airspace is correct (McLaren 1992). The data curve is very straight, showing very little heat generation in the bulk of the sludge. The analysis determined a heat load of $1.29 \mathrm{~kW}(4400 \mathrm{Btu} / \mathrm{hr})$, all concentrated in a $10.2-\mathrm{cm}$ (4-in.) layer at the bottom, with a conductivity of $.0036 \mathrm{w} / \mathrm{cm}-{ }^{\circ} \mathrm{C}$ $\left(.21 \mathrm{Btu} / \mathrm{hr}-\mathrm{ft}-{ }^{\circ} \mathrm{F}\right)$ in the bulk of the sludge. To get a best fit to the data required a $.84-\mathrm{m}$ $(2.75-\mathrm{ft})$ layer on the top of the sludge with a lower conductivity of $.0028 \mathrm{w} / \mathrm{cm}-{ }^{\circ} \mathrm{C}$ $\left(.16 \mathrm{Btu} / \mathrm{hr}-\mathrm{ft}-{ }^{\circ} \mathrm{F}\right)$. The conductivity in the bulk of the waste of this tank is lower than usual, indicating that there may not be much liquid in it. The results of the computer prediction using these parameters are shown in Figure 3-10.

\subsection{1-BY-110}

The previously published heat load for this tank was $<2.93 \mathrm{~kW}(10,000 \mathrm{Btu} / \mathrm{hr})$ (Cash et al. 1992). The thermocouple tree was located in riser R-1, which is located $2.44 \mathrm{~m}$ $(8 \mathrm{ft})$ from the center of the tank. The data used was December 8,1991 , data. The data provided gave a level variation of from $2.13 \mathrm{~m}$ to $3.87 \mathrm{~m}(7 \mathrm{ft}$ to $12.7 \mathrm{ft})$. The level used in this tank was determined from the temperature, and from neutron/gamma scan data from riser R-3 (Figure 3-11), which is also $2.44 \mathrm{~m}$ from the tank center, $180^{\circ}$ from Riser 1 . The level was determined to be $4.11 \mathrm{~m}(13.5 \mathrm{ft})$ deep. The scans indicated that the liquid content increased with depth down to about $1.83 \mathrm{~m}(6 \mathrm{ft})$ from the bottom, and remained approximately constant from there down. The gamma scan showed an increase in activity at 
Figure 3-9. Tank 241-BY-106 Temperature vs Height, Prediction vs Data and Estimation.

241-BY-106 DATA VS PREDICTIONS

$5500 \mathrm{BTU} / \mathrm{hr}$ Kcrust $=.16$, Ks ludge $=.27$

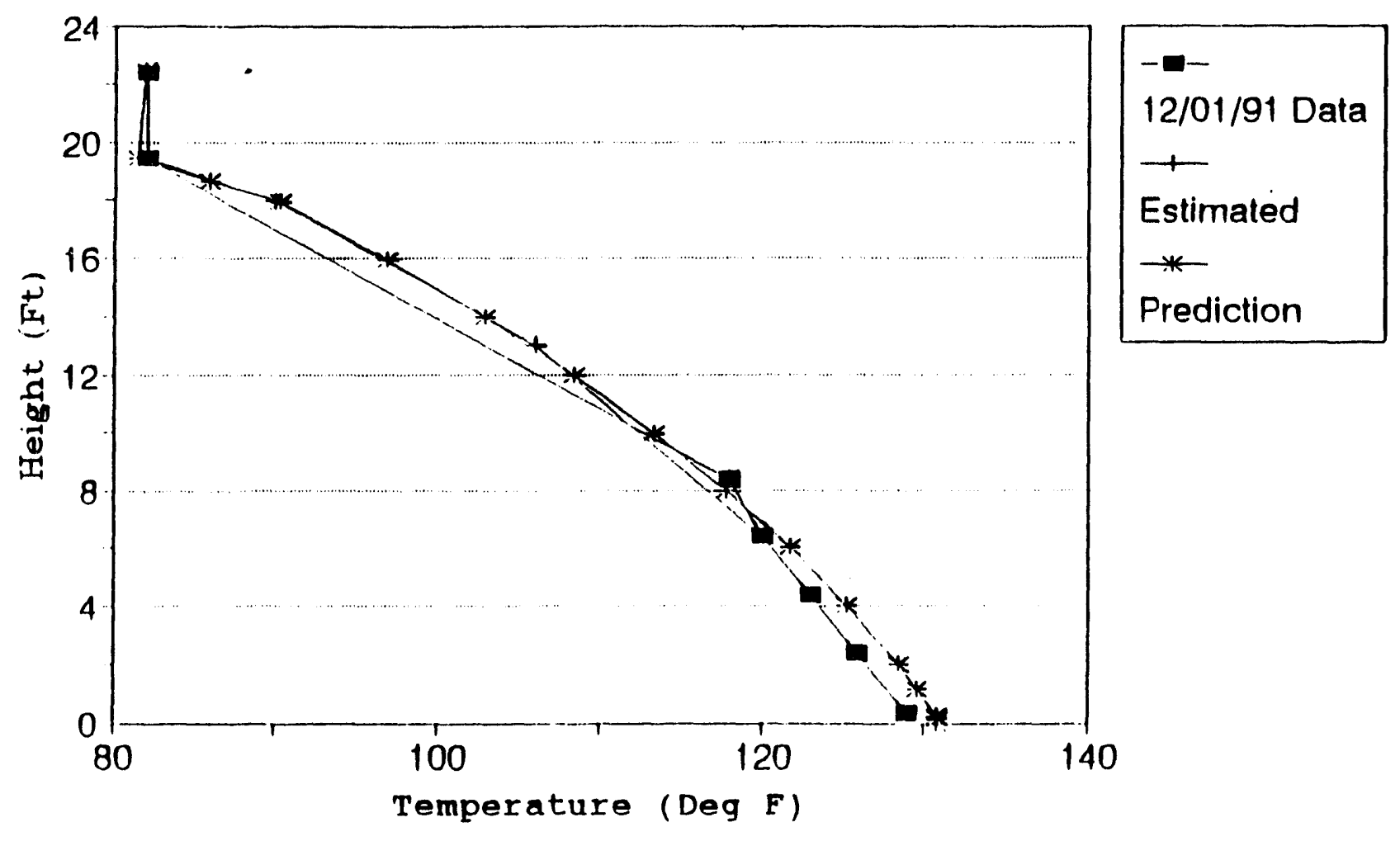


Figure 3-10. Tank 241-BY-108 Temperature vs Height, Prediction vs 29 December 1991 Data.

\section{1-BY-108 Data vs Prediction $4400 \mathrm{BTU} / \mathrm{hr}$ Kcrust $=.16$ Ks ludge $=.21$}

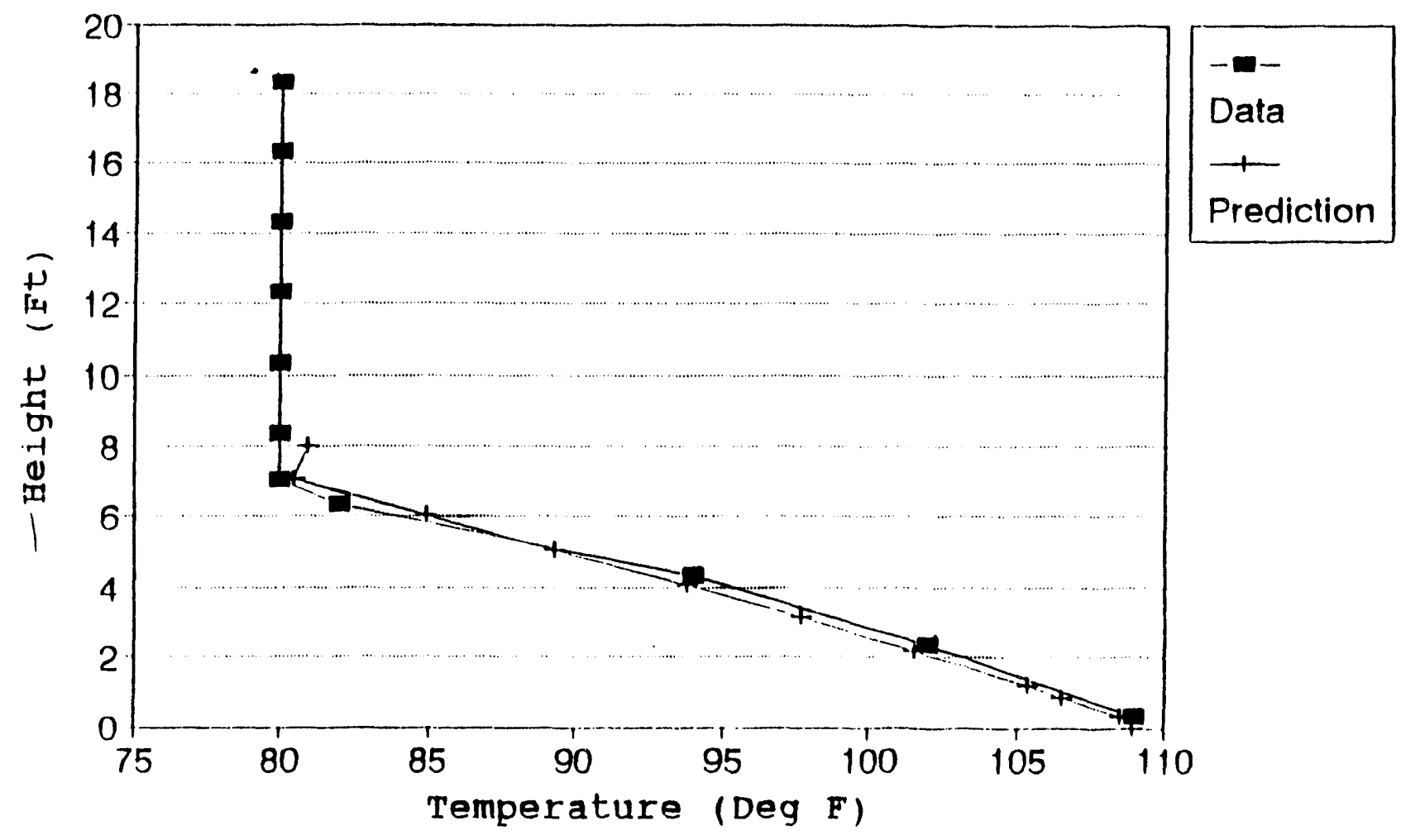


Figure 3-11. Tank 241-BY-110 Neutron and Gamma Scans vs Height, Riser 3.

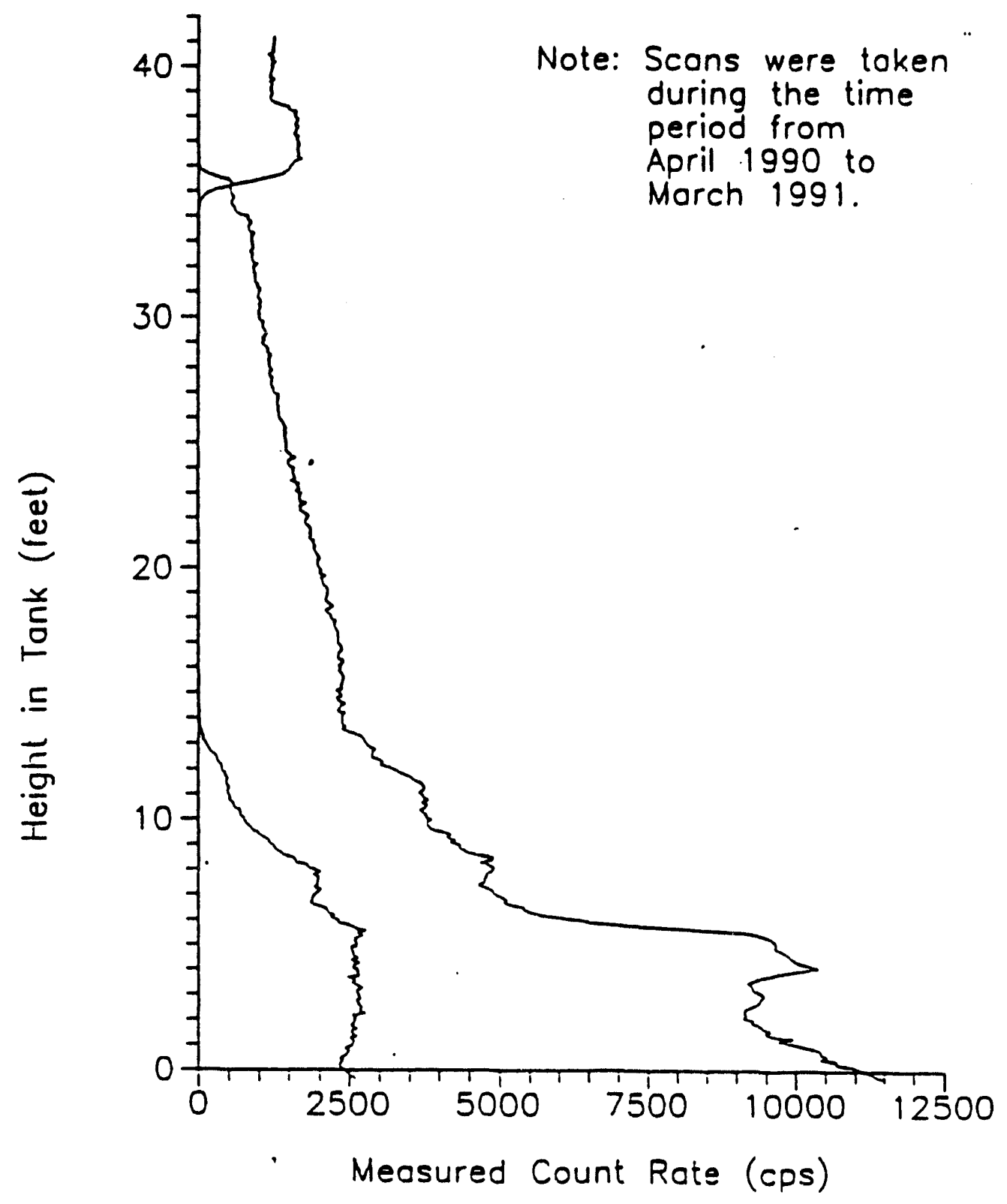


the bottom. The results of the analysis gave a heat load of $1.17 \mathrm{~kW}(4000 \mathrm{Btu} / \mathrm{hr})$, with a distribution of $1 / 2$ of the heat source in a bottom $9.8-\mathrm{cm}$ (4-in.) layer, and $1 / 2$ in a bulk region $1.66 \mathrm{~m}(5.67 \mathrm{ft})$ thick. The thermal conductivity of the sludge was $.0047 \mathrm{w} / \mathrm{cm}-{ }^{\circ} \mathrm{C}$ $\left(.27 \mathrm{Btu} / \mathrm{hr}-\mathrm{ft}-{ }^{\circ} \mathrm{F}\right)$ in a layer from the bottom to a depth of $.61 \mathrm{~m}(2 \mathrm{ft})$, and $.0036 \mathrm{w} / \mathrm{cm}-{ }^{\circ} \mathrm{C}$ $\left(.21 \mathrm{Btu} / \mathrm{hr}-\mathrm{ft}-{ }^{\circ} \mathrm{F}\right)$ in a layer from $.61 \mathrm{~m}$ to $1.83 \mathrm{~m}$ from the bottom. The rest of the waste from $1.83 \mathrm{~m}$ to the surface had a conductivity of $.0024 \mathrm{w} / \mathrm{cm}-{ }^{\circ} \mathrm{C}\left(.14 \mathrm{Btu} / \mathrm{hr}-\mathrm{ft}-{ }^{\circ} \mathrm{F}\right)$. The results of the computer predictions using these parameters are shown in Figure 3-12.

\subsection{1-BY-111}

The previously published heat load for this tank was $<2.93 \mathrm{~kW}(10000 \mathrm{Btu} / \mathrm{hr})$ (Cash et al. 1992). The temperature data from this tank were taken by inserting a thermocouple into a LOW (riser R-1), pressing it against the wall with an inflated bladder, and recording the reading. The thermocouple was then moved to a different elevation and the process was repeated. The gamma/neutron scans were also taken in riser R-1, which is

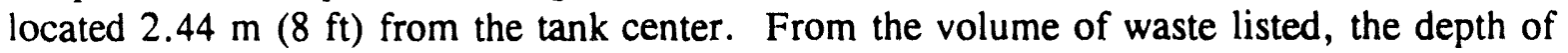
the waste is $4.21 \mathrm{~m}(13.8 \mathrm{ft})$. This level was used in the model. The shape of the temperature vs height curve indicated that the heat generation was at least partially spread throughout the waste, and not all concentrated at the bottom. The analysis determined that the heat load was $.70 \mathrm{~kW}(2400 \mathrm{Btu} / \mathrm{hr})$, generated in the lower $1.52 \mathrm{~m}(5 \mathrm{ft})$ of the waste. The conductivities of the waste were computed to be $.0047 \mathrm{w} / \mathrm{cm}-{ }^{\circ} \mathrm{C}\left(.27 \mathrm{Btu} / \mathrm{hr}-\mathrm{ft}-{ }^{\circ} \mathrm{F}\right)$ in the lower $3.72 \mathrm{~m}(12.2 \mathrm{ft})$, and $.0028 \mathrm{w} / \mathrm{cm}-{ }^{\circ} \mathrm{C}\left(.16 \mathrm{Btu} / \mathrm{hr}-\mathrm{ft}-{ }^{\circ} \mathrm{F}\right)$ in the top $.96 \mathrm{~m}(3.16 \mathrm{fi})$, the crust. These results are shown in Figure 3-13.

\subsection{HEAT LOAD VS AIR TEMPERATURE}

The possibility of using the airspace temperature in an unventilated tank to approximate the heat load was proposed by D. M. Ogden two years ago. At that time there were insufficient data to investigate the proposal. With the analysis of these six tanks, a cursory investigation can be made. The heat loads of the investigated tanks were plotted against their airspace temperatures. No effort was made to correct for the varying differences in soil cover. The results are shown in Figure 3-14. These results indicate that the airspace temperature could be used to approximate the heat load of an unventilated tank, at least within some limits. The plot shown could be used to evaluate unventilated tanks with airspace temperatures from $18.3^{\circ} \mathrm{C}$ to $29.4^{\circ} \mathrm{C}\left(65^{\circ} \mathrm{F}\right.$ to $\left.85^{\circ} \mathrm{F}\right)$, with an accuracy of plus or minus $.29 \mathrm{~kW}$ ( $1000 \mathrm{Btu} / \mathrm{hr}$ ). While this appears to be a wide uncertainty band, it is still good enough to check the published values of the heat loads of the waste storage tanks, many of which are known to be in error. It certainly can tell whether the published heat loads of over $5.86 \mathrm{~kW}$ $(20,000 \mathrm{Btu} / \mathrm{hr})$ are correct. As more data become available the procedure can be refined. 
Figure 3-12. Tank 241-BY-110 Temperature vs Height,

Predictions vs 8 December 1991 Data.

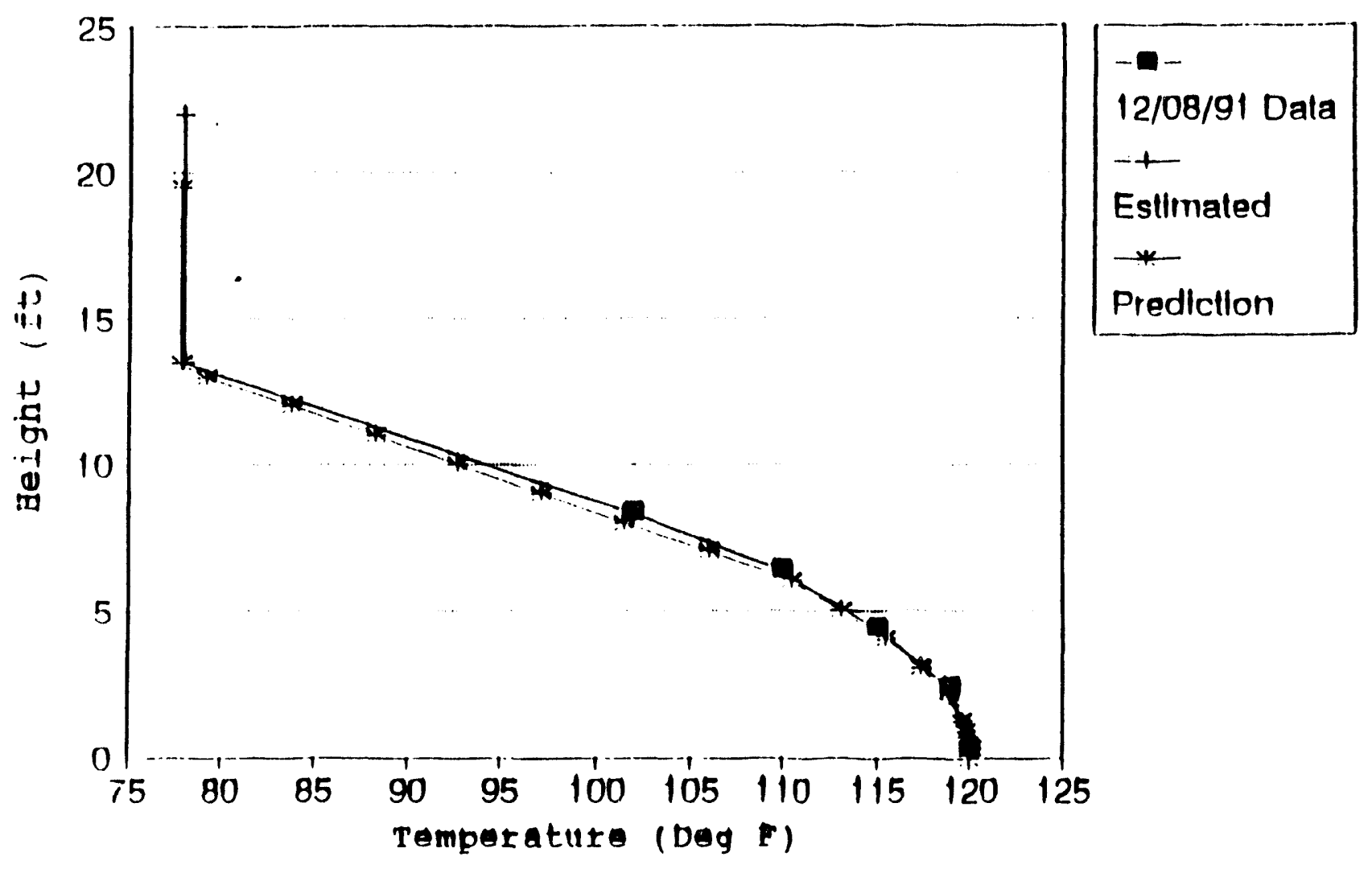


Figure 3-13. Tank 241-BY-111 Data Vs Prediction.

$2400 \mathrm{BTU} / \mathrm{hr}$ Kcrust $=.16$ Ksludge $=.27$

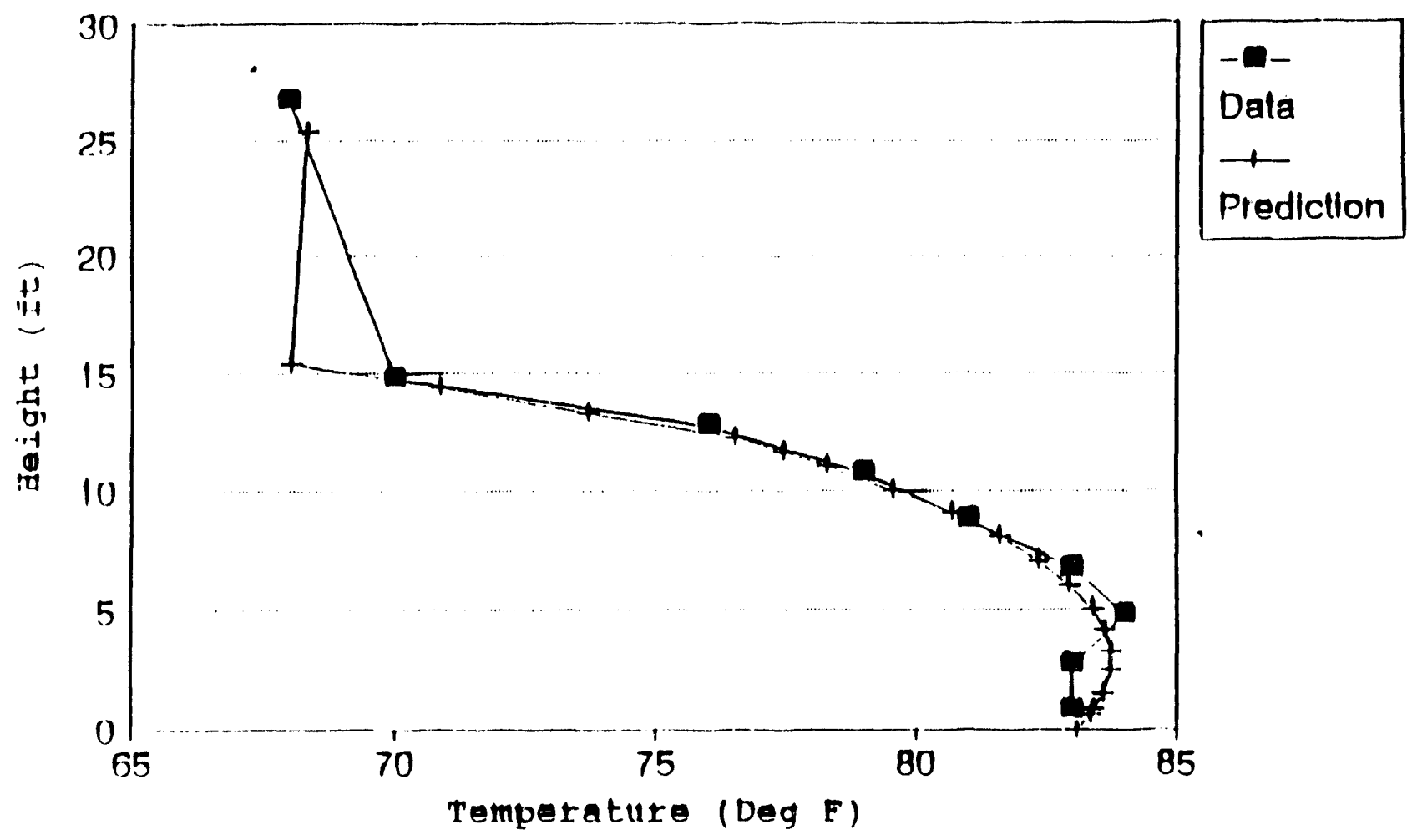


Figure 3-14. Heat Load vs Temperature.

so11 Cover Not Compensated

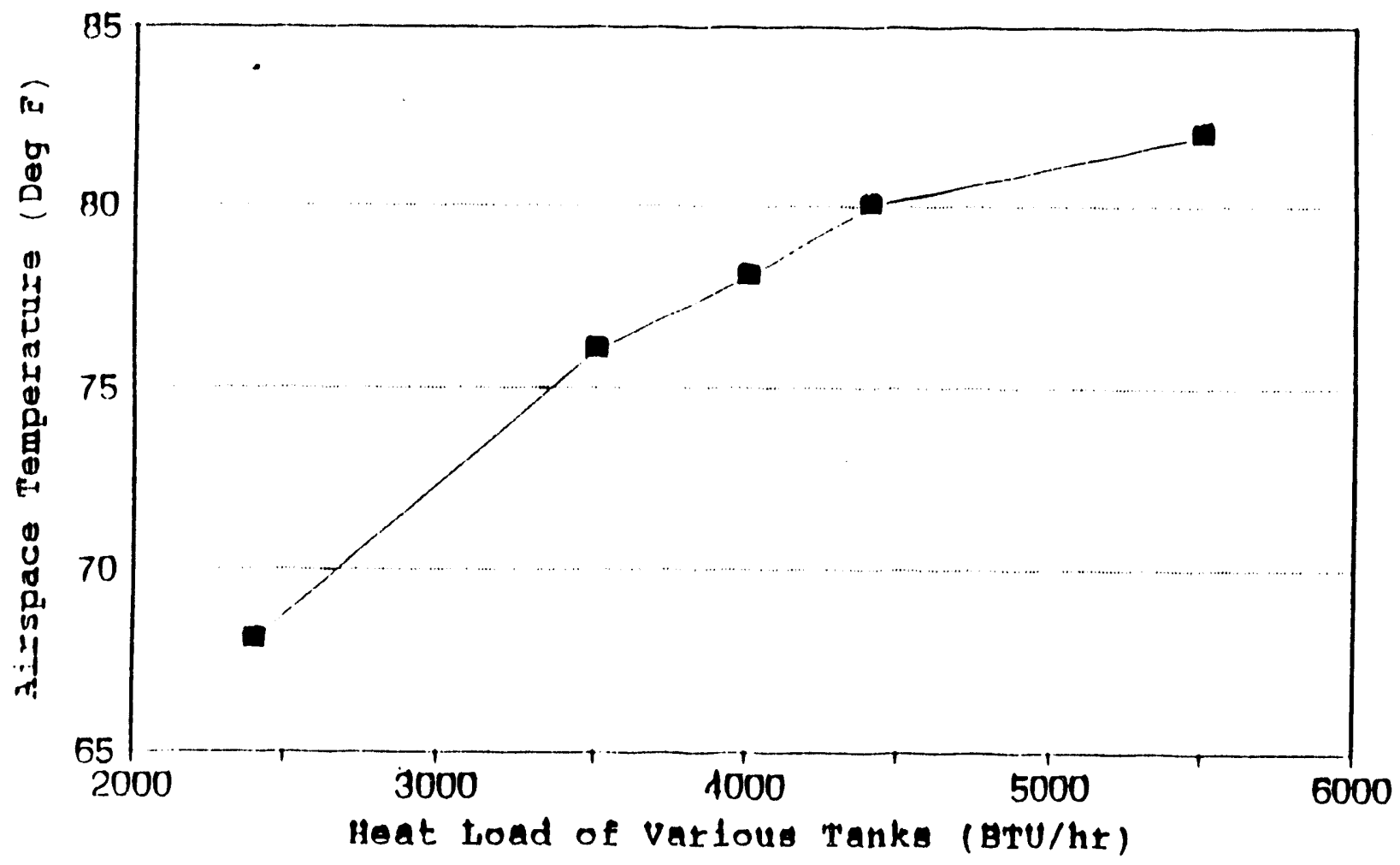




\subsection{SUMMARY OF RESULTS}

A summary of the results of the analysis is shown in Table 3-1 below.

Table 3-1. Summary of Results.

\begin{tabular}{|c|c|c|c|c|c|}
\hline \multirow[t]{2}{*}{ Tank } & \multirow{2}{*}{$\begin{array}{c}\text { Heat load } \\
\text { Btu/hr }\end{array}$} & $\mathrm{K}_{\text {wet }}$ & $K_{\text {demp }}$ & $\mathbf{K}_{\text {crust }}$ & \multirow[t]{2}{*}{ Heat distribution } \\
\hline & & \multicolumn{3}{|c|}{$\mathrm{Btu} / \mathrm{hr}-\mathrm{ft}-{ }^{\circ} \mathrm{F}$} & \\
\hline 105-BY & 4000 & .27 & & .23 & All in bottom 3 in. \\
\hline 106-BY & 5500 & .27 & & .16 & $1 / 2$ in bottom 3 in., $1 / 2$ in bulk of sludge \\
\hline 108-BY & 4400 & .21 & .21 & .16 & All in bottom 4 in. \\
\hline 110-BY & 4000 & .27 & .21 & .14 & $1 / 2$ in bottom 4 in., $1 / 2$ in bulk of sludge \\
\hline 111-BY & 2400 & .27 & & .16 & Homogeneous in sludge \\
\hline $109-C$ & 3500 & .27 & & & No predictions due to lack of data \\
\hline
\end{tabular}

An improved model and method of analyzing the single-shell waste storage tanks was developed since this analysis (McLaren 1993). It was found that the tanks were not as close to a quasi-steady-state condition as previously supposed. The analysis method used in this document is a steady state analysis. The new method uses improved soil conductivity values and a transient analysis from the time the tanks were filled with ferrocyanide wastes. As a result of the new method, the heat loads of these tanks were found to be higher than previously calculated. A factor of 1.6 was calculated to be used to update the results of the analyses reported in this document. These values have an uncertainty band of \pm 38 percent. Table 3-2 indicates the new, more accurate values for the heat loads of these tanks.

Table 3-2. Corrected Values for Heat Loads.

\begin{tabular}{|l|c|c|}
\hline \multicolumn{1}{|c|}{ Tank number } & Old value $(\mathrm{kW}-\mathrm{Btu} / \mathrm{hr})$ & $\begin{array}{c}\text { Corrected value }(\mathrm{kW}- \\
\text { Btu/hr) }\end{array}$ \\
\hline $241-\mathrm{BY}-105$ & $1.17-4000$ & $1.88-6400$ \\
\hline $241-\mathrm{BY}-106$ & $1.61-5500$ & $2.58-8800$ \\
\hline $241-\mathrm{BY}-108$ & $1.29-4400$ & $2.06-7000$ \\
\hline $241-\mathrm{BY}-110$ & $1.17-4000$ & $1.88-6400$ \\
\hline $241-\mathrm{BY}-111$ & $0.07-2400$ & $1.13-3800$ \\
\hline $241-\mathrm{C}-109$ & $1.03-3500$ & $1.64-5600$ \\
\hline
\end{tabular}


This page intentionally left blank. 


\subsection{CONCLUSIONS}

This analysis revealed no values that were unexpected. The existence of the heat-generating radionuclides being concentrated in a layer on or near the bottom of a waste storage tank has been previously considered. These layers were found in two of the tanks: 241-BY-105 and -108. A concentration of part of the heat load into a bottom layer was found in two of the tanks: 241-BY-106 and -110. Homogeneous distribution of the heat source was found in one of the tanks: 241-BY-111. No prediction about the heat distribution in tank 241-C-109 could be made because of the lack of temperature data in this tank.

Two tanks indicated large volumes of lower conductivity: $241-\mathrm{BY}-108$ and -110 . The conductivity for $241-\mathrm{BY}-108$ was $.0036 \mathrm{w} / \mathrm{cm}-{ }^{\circ} \mathrm{C}\left(.21 \mathrm{Btu} / \mathrm{hr}-\mathrm{ft}-{ }^{\circ} \mathrm{F}\right)$ through the entire sludge region, except for the bottom $10.2 \mathrm{~cm}(4 \mathrm{in}$.). The conductivity for tank $241-\mathrm{BY}-110$ was determined to be $.0047 \mathrm{w} / \mathrm{cm}-{ }^{\circ} \mathrm{C}\left(.27 \mathrm{Btu} / \mathrm{hr}-\mathrm{ft}-{ }^{\circ} \mathrm{F}\right)$ only in the bottom .61 (2 ft) of the sludge. A layer of lower conductivity existed in the $1.22-\mathrm{m}(4-\mathrm{ft})$ layer above that, with a lower than usual conductivity in the crust above it. This could be indicative of less liquid in these tanks.

These waste storage tanks have much lower heat loads than previously calculated (Hanlon 1991). The thermal conductivity of their contents is within the range previously determined by laboratory analysis. They also lie within the ranges predicted by previous computer analysis. The distribution of the heat source in the tanks ranges from nearly homogeneous to being concentrated in a thin layer on the bottom. Other than a bottom layer, there is no evidence of layering anywhere else in the tanks. 
This page intentionally left blank. 


\subsection{REFERENCES}

Allen, G. K., 1992, HEATING7 Code Validation/Verification, WHC-SD-WM-ER-100, Westinghouse Hanford Company, Richland, Washington.

Bouse, D. G., 1975, Thermal Conductivity of Hanford Waste Solids and SX Farm Soil Samples, ARH-CD-378, Atlantic Richfield Hanford Company, Richland, Washington.

Burger, L. L., 1989, Complexant Stability Investigation, Task 1-Ferrocyanide Solids, PNL-5441, Pacific Northwest Laboratory, Richland, Washington.

Burger, L. L. and R. D. Scheele, 1988, Interim Report, Cyanide Safety Studies, PNL-7175, Pacific Northwest Laboratory, Richland, Washington.

Cash, R. J., G. T. Dukelow, and J. M. Atwood, 1992, Quarterly Report on Defense Facility Safety Board Recommendation 90-7 for the Period Ending December 31, 1991, WHC-EP-0474-3, Westinghouse Hanford Company, Richland, Washington.

Hanlon, B. M., 1991, Tank Farm Surveillance and Waste Status Report for August 1991, WHC-EP-0182,41, Westinghouse Hanford Company, Richland, Washington.

McLaren, J. M., 1991, Single-Shell Tank 104-BY Thermal Hydraulic Analysis, WHC-EP-0521, Westinghouse Hanford Company, Richland, Washington.

McLaren, J. M., 1992, FATHOMS Analysis of Tank 104 BY, WHC-SD-WM-ER-137, Rev. 1, Westinghouse Hanford Company, Richland, Washington.

McLaren, J. M., 1993, Ferrocyanide Safety Program: Updated Thermal Analysis Model for Ferrocyanide Tanks with Application to Tank 241-BY-104, WHC-EP-0669, Rev. 0, Westinghouse Hanford Company, Richland, Washington. 
This page intentionally left blank. 
WHC-EP-0638

APPENDIX A

A-1 
This page intentionally left blank. 


\section{APPENDIX A}

The three major factors for determining the heat load and thermal characteristics of a waste storage tank are interrelated. These factors are (1) heat load (Btu/hr); (2) distribution of the heat source within the tank; and (3) thermal conductivity of the waste within the tank (a function of height). The heat load is a major factor in the maximum temperature within the tank and the airspace temperature in the tank. The heat source distribution is a major factor in the shape (curvature) of the temperature-vs-height curve. The thermal conductivity is a major factor in the slope of the temperature-vs-height curve. However, these factors do not stand alone; each has an influence on all features of the temperature-vs-height curve. The following discussion with examples will demonstrate this. In this Appendix, heat loads are in Btu/hr, and thermal conductivities are in Btu/hr-ft- ${ }^{\circ} \mathrm{F}$.

The figures from the analysis of tank 241-BY-111 illustrate some of the interrelationship of the three parameters to be determined. Figure A-1 shows how the distribution of the heat source alters the shape of the temperature-vs-height curve. One curve shows the effect of a heat source distribution that is homogeneously distributed between 0 and $13 \mathrm{ft}$. The other shows a heat source that is concentrated in a 4-in. layer at the bottom. The two curves are quite different. The slope of the curves from $13 \mathrm{ft}$ to $14.5 \mathrm{ft}$ are not equal, although they are close, even though the thermal conductivities are the same and there is no heat source in this region. If the heat load and heat source distribution are kept constant and the thermal conductivities are varied, as shown in Figure A-2, not only does the slope of the curve change, but the maximum temperature changes as well. Note, however, that the airspace temperatures at the $25-\mathrm{ft}$ level change very little. If the heat source distribution and conductivities are held constant and the heat load is varied, as in Figure A-3, not only does the maximum temperature change, but the shapes of the curves change as well. The higher heat loads show more curvature with a more pronounced reflex in the 0 - to 3 - $\mathrm{ft}$ region.

To illustrate the use of these factors, the analysis of tank $241-\mathrm{BY}-110$ will be examined in detail. The use of the terms "wet," "damp," and "dry" is to differentiate between volumes of various conductivities. The first step is to plot and examine the temperature-vs-height data. This is shown in Figure A-4. If a vertical line is dropped from the airspace temperature reading at $22 \mathrm{ft}$ to the calculated waste surface level, and another line from there to the highest data point in the sludge $(8 \mathrm{ft})$, the result is a line that is very nearly straight from the 6 - $\mathrm{ft}$ level to the surface. The shape of the curve below $6 \mathrm{ft}$ is indicative of a uniform heat generation from $6 \mathrm{ft}$ down. However, the lack of a reflex in the data temperature curve, coupled with the continuing temperature increase all the way to the bottom, is indicative of a layer that is generating heat at the bottom. Therefore, start with a heat load of $3500 \mathrm{Btu} / \mathrm{hr}$ with a distribution of $2 / 3$ of the total heat in a 4 -in. layer at the bottom, and $1 / 3$ of the total heat in a layer from $6 \mathrm{ft}$ to 4 -in. Use a low conductivity, .10, from $6 \mathrm{ft}$ to the surface, the "crust" or "dry" layer, with a higher conductivity, .12, from $6 \mathrm{ft}$ to $2 \mathrm{ft}$, a "damp" layer. Use a higher conductivity, .27, from $2 \mathrm{ft}$ to the bottom, a "wet" layer. This curve is shown in Figure A-5. The curve does not denote 


\section{WHC-EP-0638}

Figure A-1. 241-BY-111 Data vs Predictions.

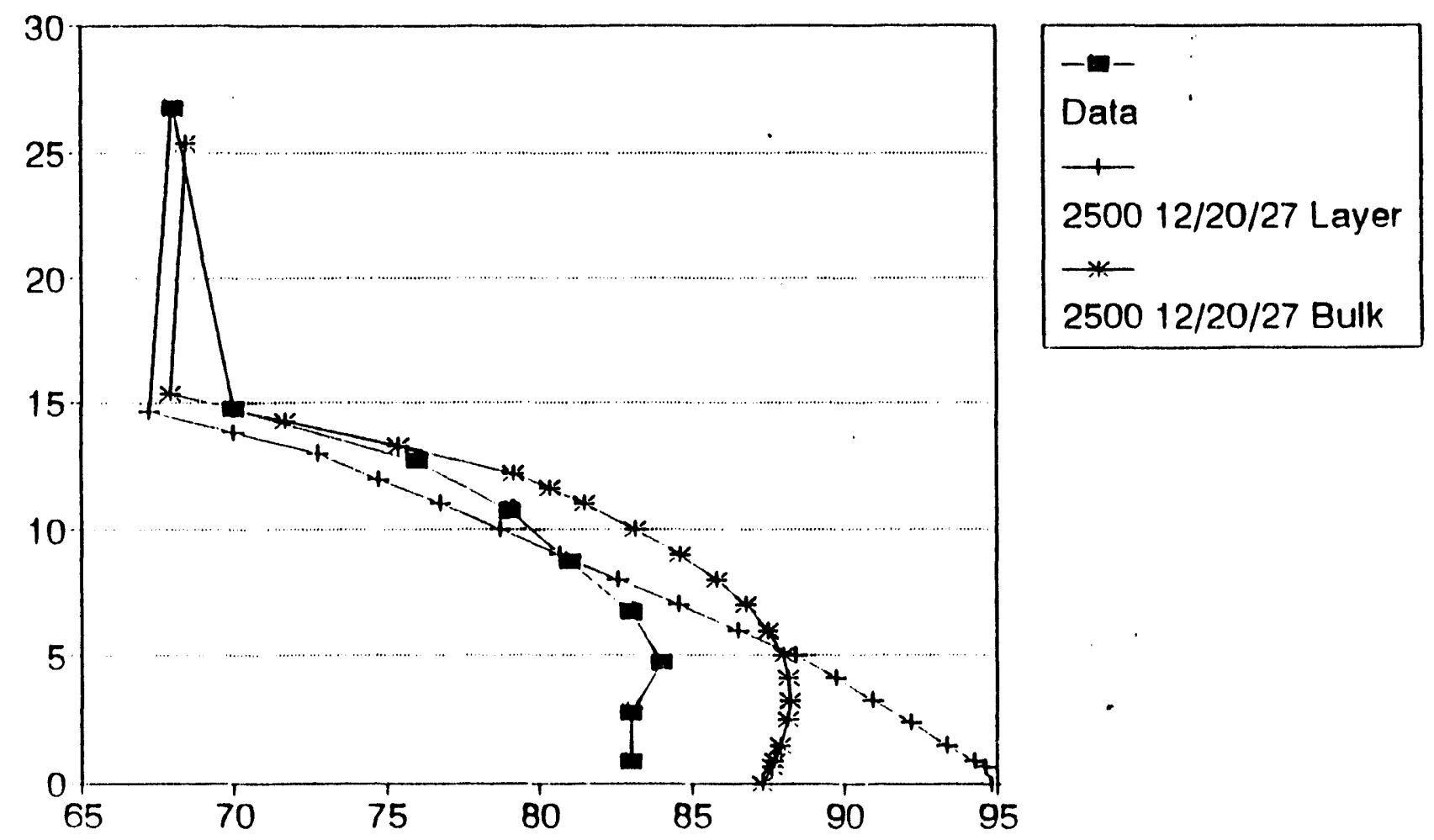




\section{WHC-EP-0638}

Figure A-2. 241-BY-111 Data vs Predictions.

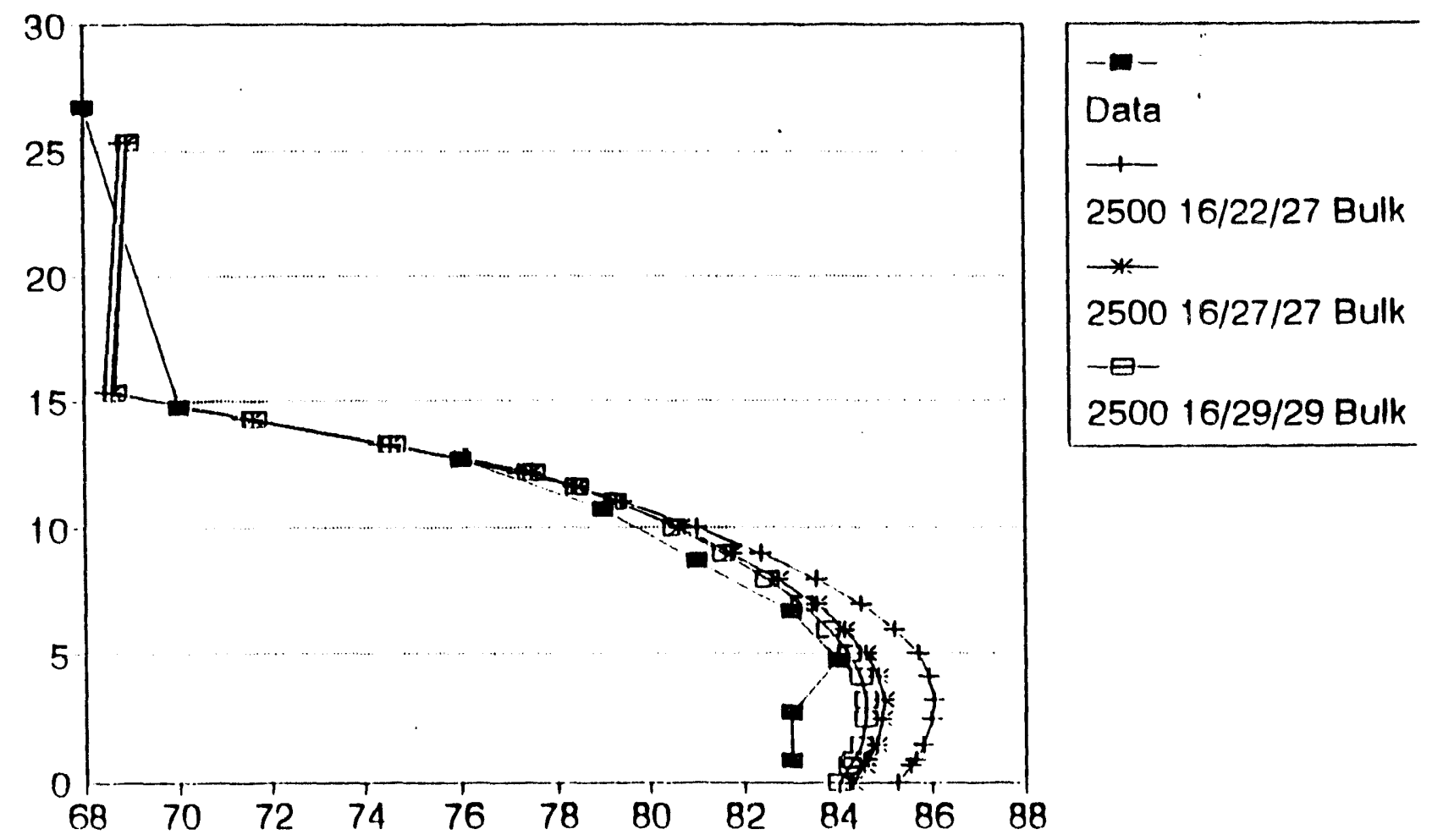


Figure A-3. 241-BY-111 Data vs Predictions.

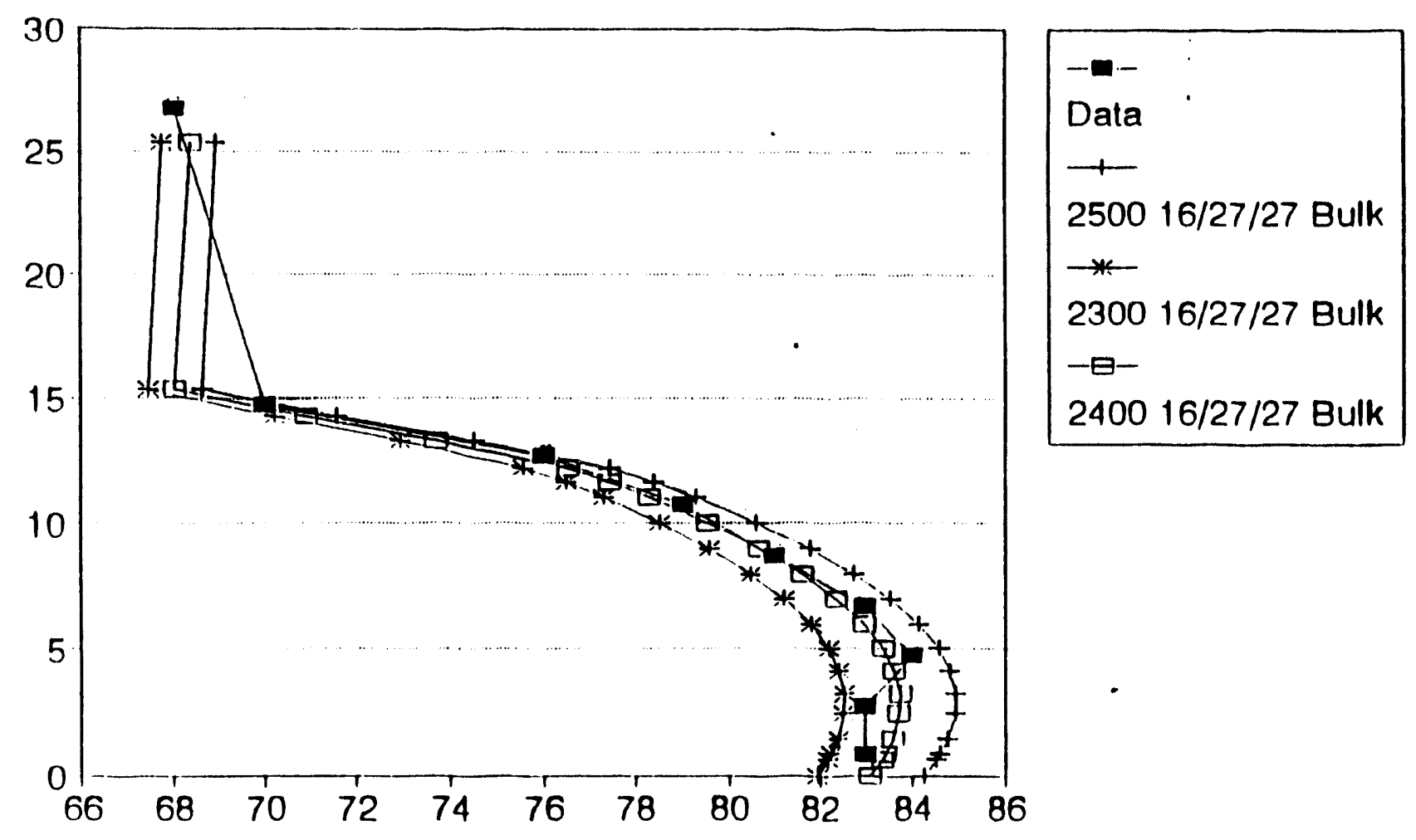




\section{WHC-EP-0638}

Figure A-4. 241-BY-110, 12 December 1991 Data.

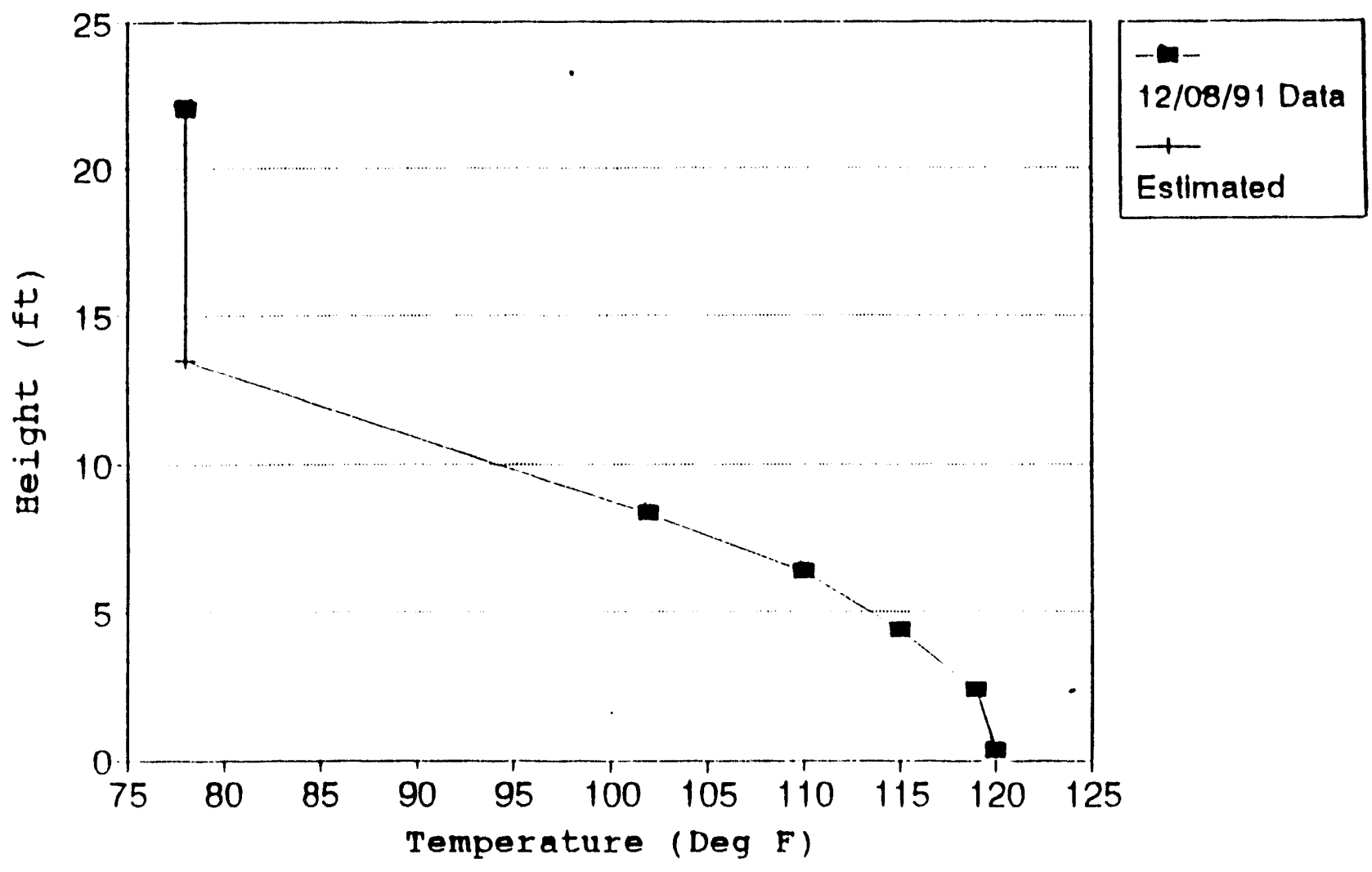


Figure A-5. 241-BY-110 Predictions vs Data, $3500 \mathrm{Btu} / \mathrm{hr}$ Various Ks.

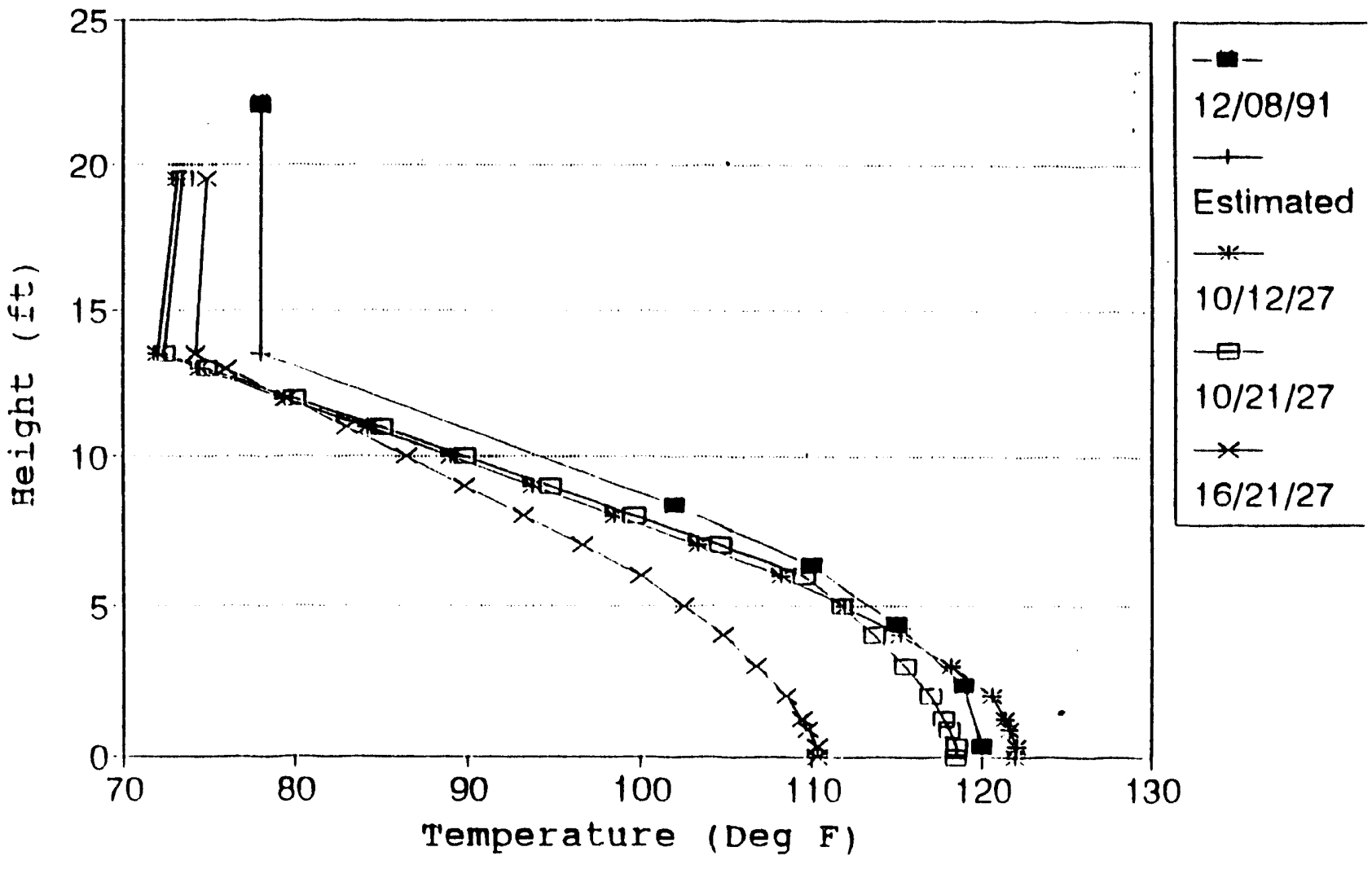


that the waste is in fact dry or wet. The maximum temperature is too high, and the slopes are too flat. Therefore, the conductivity is increased in the $2-\mathrm{ft}$ to 6 - $\mathrm{ft}$ "damp" layer to .21. The results of this prediction are also shown in Figure A-5. The shape of this curve approaches the data, but the slope through the "dry" region is too flat. The conductivities of the lower regions are therefore retained and increased in the "dry" region to .16. This curve is also shown in Figure A-5.

This change causes the whole curve to shift to the cooler side, and markedly increases the slope of the curve. The airspace temperatures are also too low, so the heat load is increased to $4000 \mathrm{Btu} / \mathrm{hr}$, with all other parameters held constant. These results are shown in Figure A-6. The airspace temperature is very close, as is the maximum temperature. The rest of the curve does not show the same curvature. The "dry" conductivity is reduced to .13, and all other parameters are kept the same as before. These results are shown on Figure A-7. They look much better than before; however, there are some important mismatches. At the bottom, the curve does not drop steeply enough, indicating that there is probably too much heat in the layer. As a change here will affect the curve elsewhere, the other parameters are not changed. A new distribution of $1 / 3$ of the total heat in this layer and $2 / 3$ of the total heat in the layer from 4 in. to $6 \mathrm{ft}$ is used. These results are plotted in Figure A-8.

These results show that the maximum temperature is reduced, and the curve begins to show a reflex. However, there is too much curvature at the bottom of the curve, and too much heat in the bulk of the waste. Consequently, the distribution is changed to $1 / 2$ in the 4-in. layer and $1 / 2$ in the bulk region. These results are also plotted in Figure A-8. They show a better match to the shape of the data curve, but are still too high a maximum temperature, and too flat a slope from $6 \mathrm{ft}$ to the surface. If the conductivity of the "dry" layer is reduced, the slope will increase and the maximum temperature will be reduced. The conductivity of .16 is used in the "dry" layer, with all other parameters held constant. These results are shown in Figure A-9. They show that this conductivity shift is too much. It makes the slope of the "dry" region too steep, and reduces the maximum temperature too much. It appears that splitting the difference between the .13 and .16 conductivity figures is good, (i.e. .145). However, these changes are not linear results; they tend to act in a logarithmic fashion. The "dry" conductivity is adjusted to .14 and the results observed. These are shown in Figure A-10. They show a very good fit at the lower end of the curve. Above $8 \mathrm{ft}$ there is some mismatch, but this is in the area of the estimated curve. The overall fit is close enough. The noding diagram for this model, and the computer input, are shown as Figures A-11 and $\mathrm{A}-12$.

This is typical of the procedure used to develop the heat load and thermal characteristics of the Hanford Site waste storage tanks. It requires consistent data, as a "one-off" reading that is used as data will produce very different results. All the data used in this study were checked for consistency prior to use. Comparing the gamma and neutron scan data in Figure A-6 with the temperature data for R-10C (Figure A-5) provides some interesting correlations. Between 0 and $4 \mathrm{ft}$ from the bottom, the temperature drop is almost constant, and the neutron data shows a constant moisture. Between 4 and $6 \mathrm{ft}$ from the bottom, the temperature drops more rapidly, indicating a lower conductivity. The neutron 
scan also shows a drop in this region, indicating a reduced amount of liquid. The gamma scan also shows a marked reduction in activity in this region, which is also indicative of a reduced liquid content, as there is much activity in the liquid. From 6 to $8 \mathrm{ft}$ above the bottom the temperature drop is less than before, indicating a higher conductivity. The neutron scan shows an increase in the amount of liquid in the region, as does the gamma scan. It appears that there is a more dense layer in the region 4 to $6 \mathrm{ft}$ from the bottom, with less interstitial liquid, resulting in decreased activity and conductivity. Unfortunately, there is no temperature data above $8 \mathrm{ft}$ from the bottom in the waste in this area, or more information could be determined. 
WHC-EP-0638

Figure A-6. 241-BY-110 Predictions vs Data,

$\mathrm{Ks}=.16 / .21 / .27$ Various Heats.

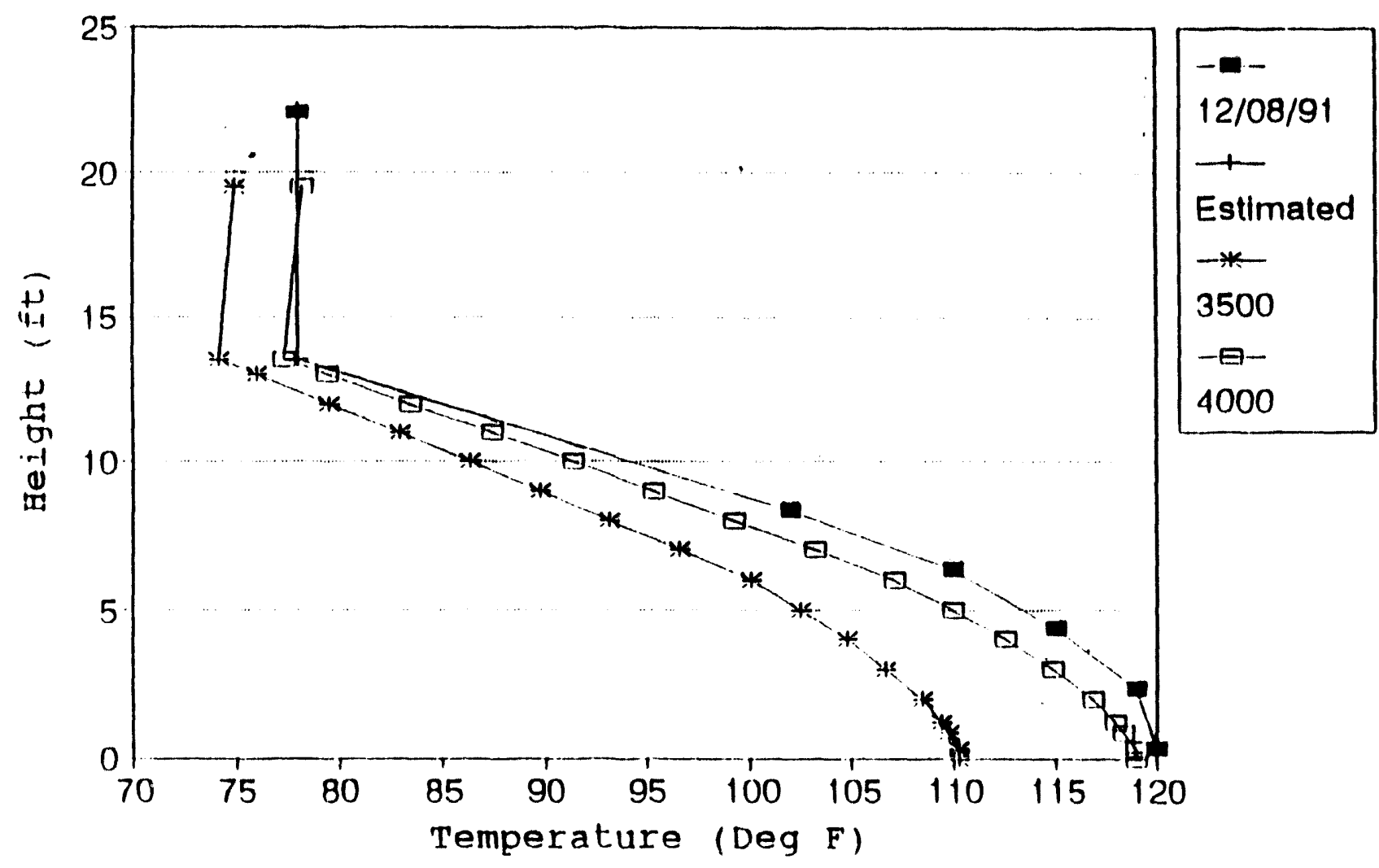


Figure A-7. 241-BY-110 Predictions vs Data, $4000 \mathrm{Btu} / \mathrm{hr}$ Various Ks.

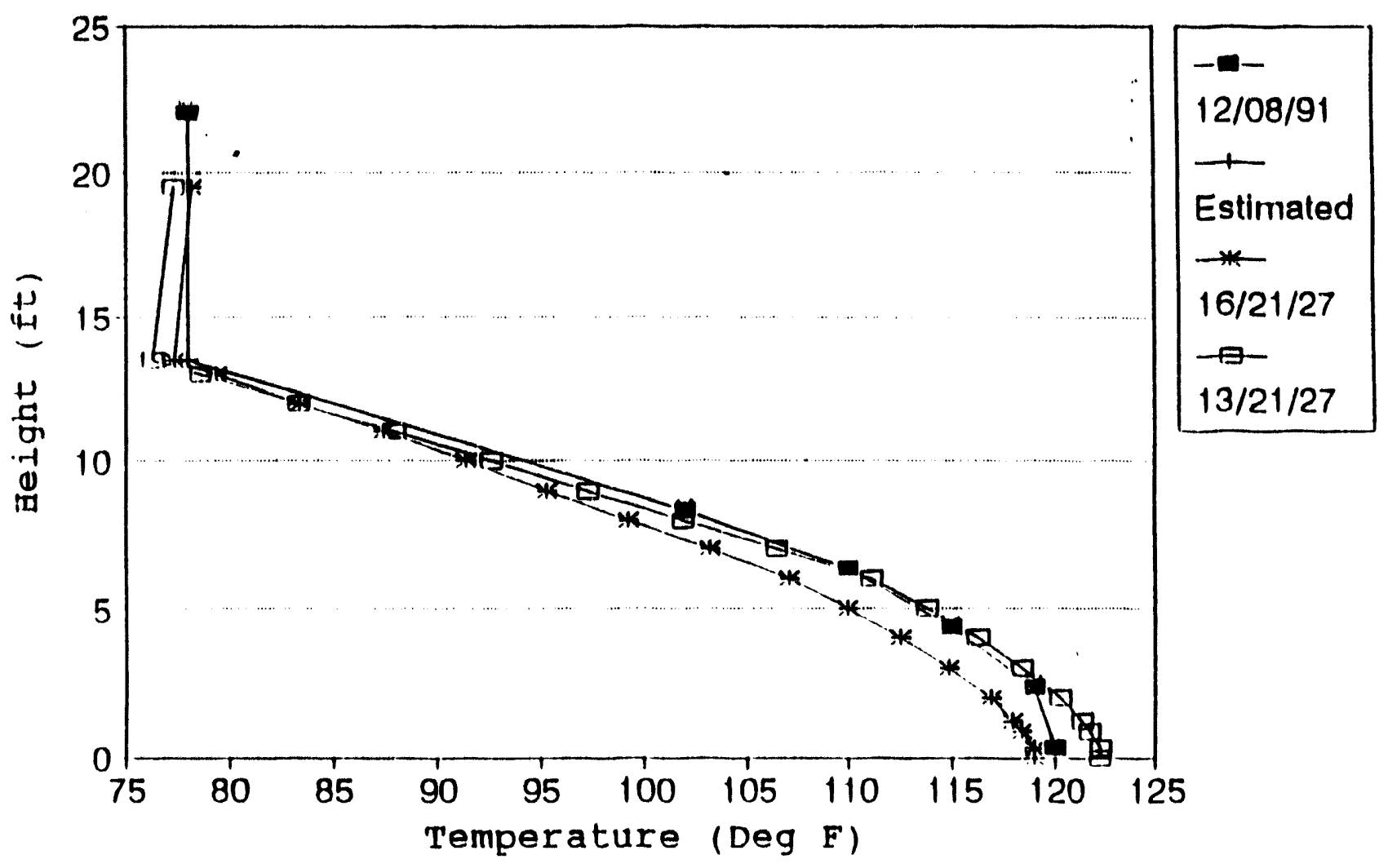


Figure A-8. 241-BY-110 Predictions vs Data, $4000 \mathrm{Btu} / \mathrm{hr} \mathrm{K}=.13 / .21 / .27$.

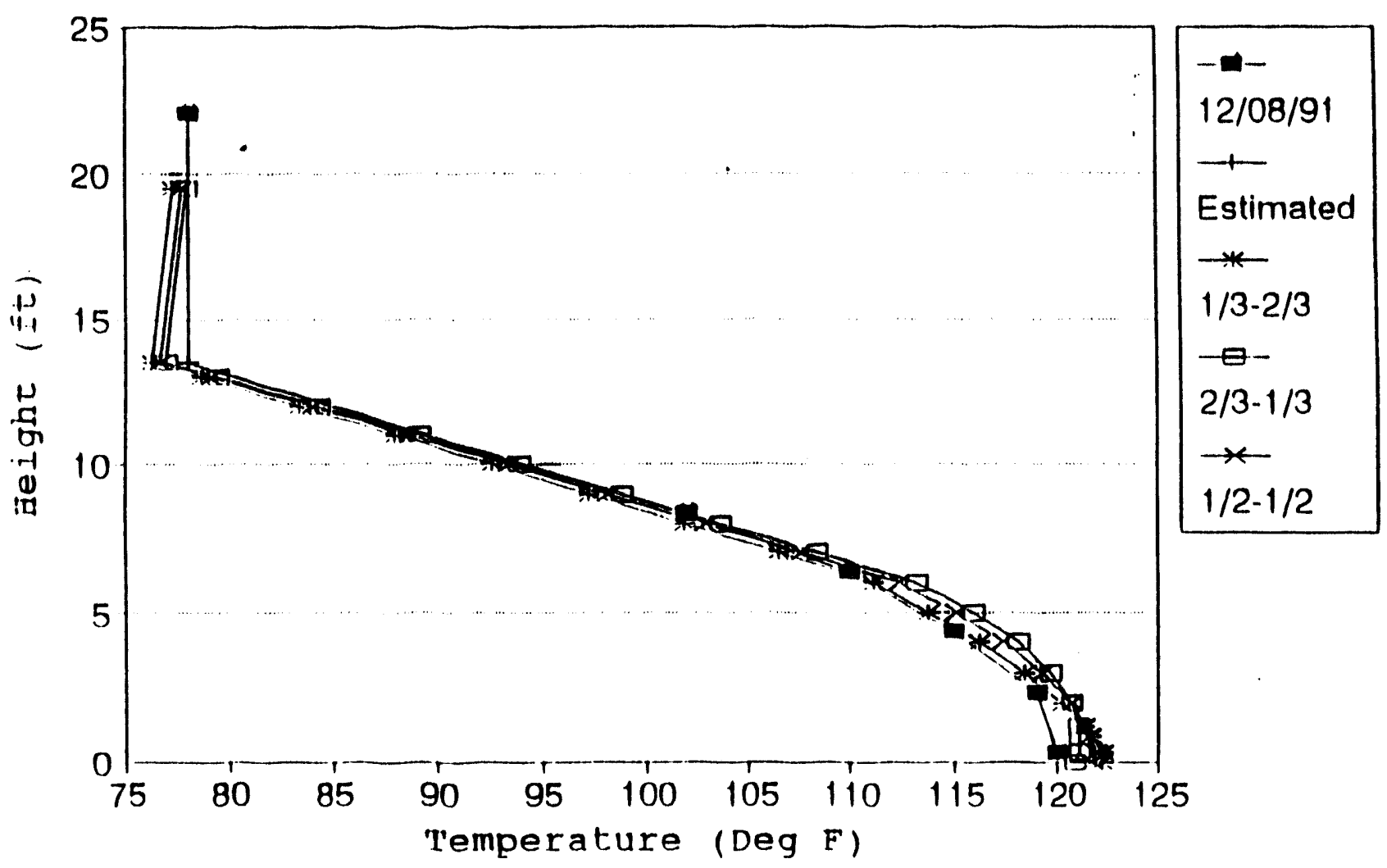


Figure A-9. 241-BY-110 Predictions vs Data, $4000 \mathrm{Btu} / \mathrm{hr}$ Various Ks.

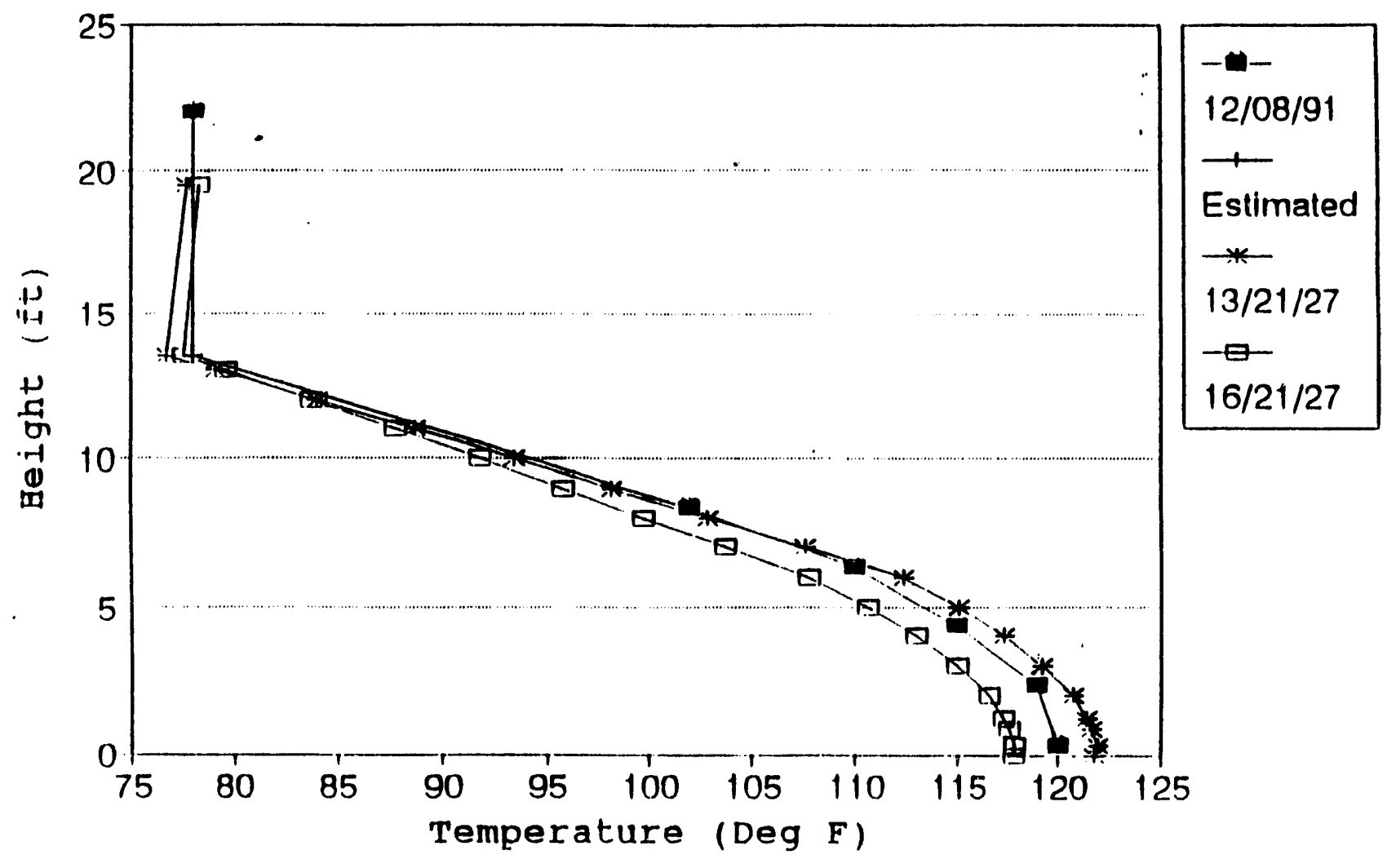




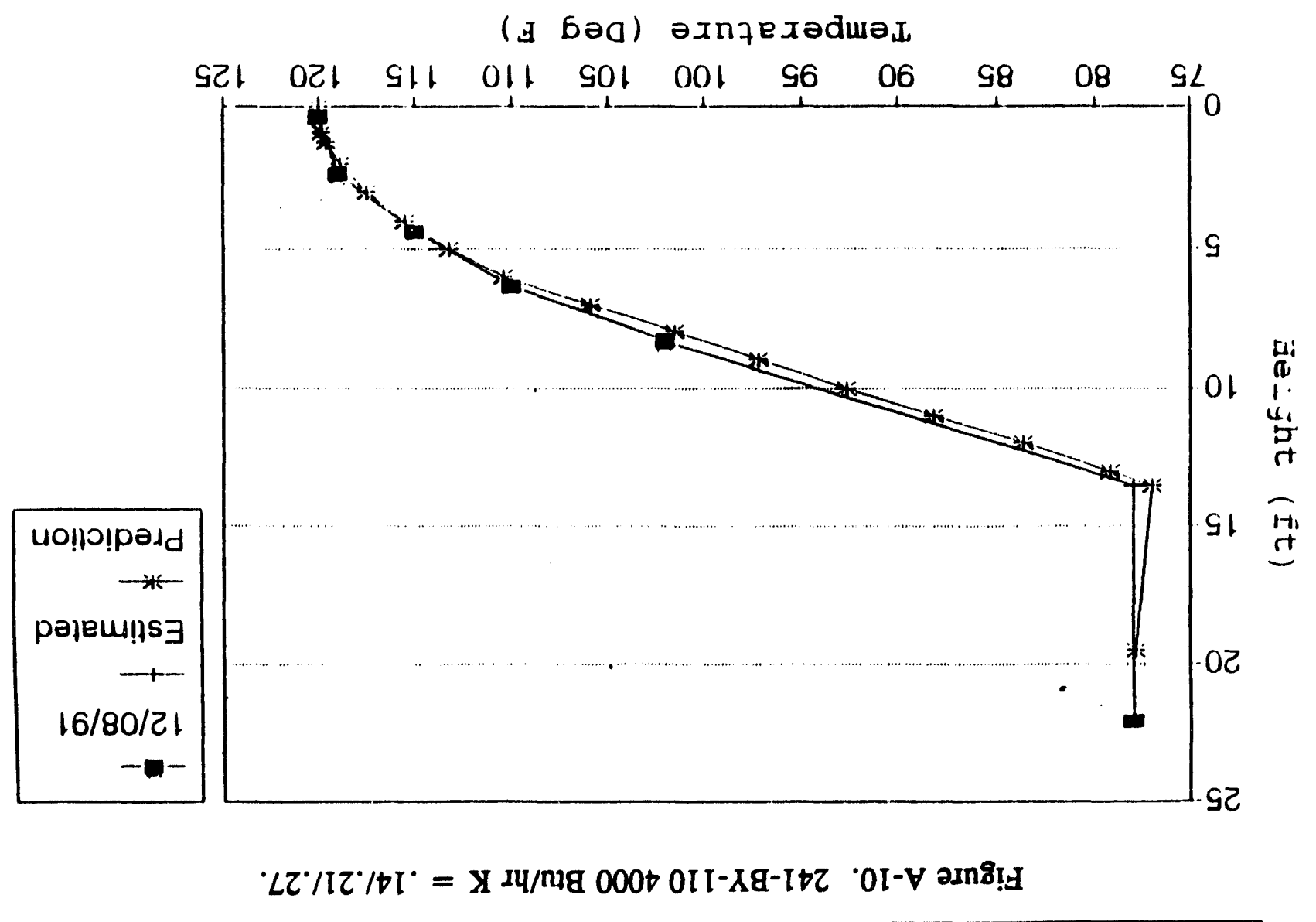


Figure A-11. 241-BY-110.

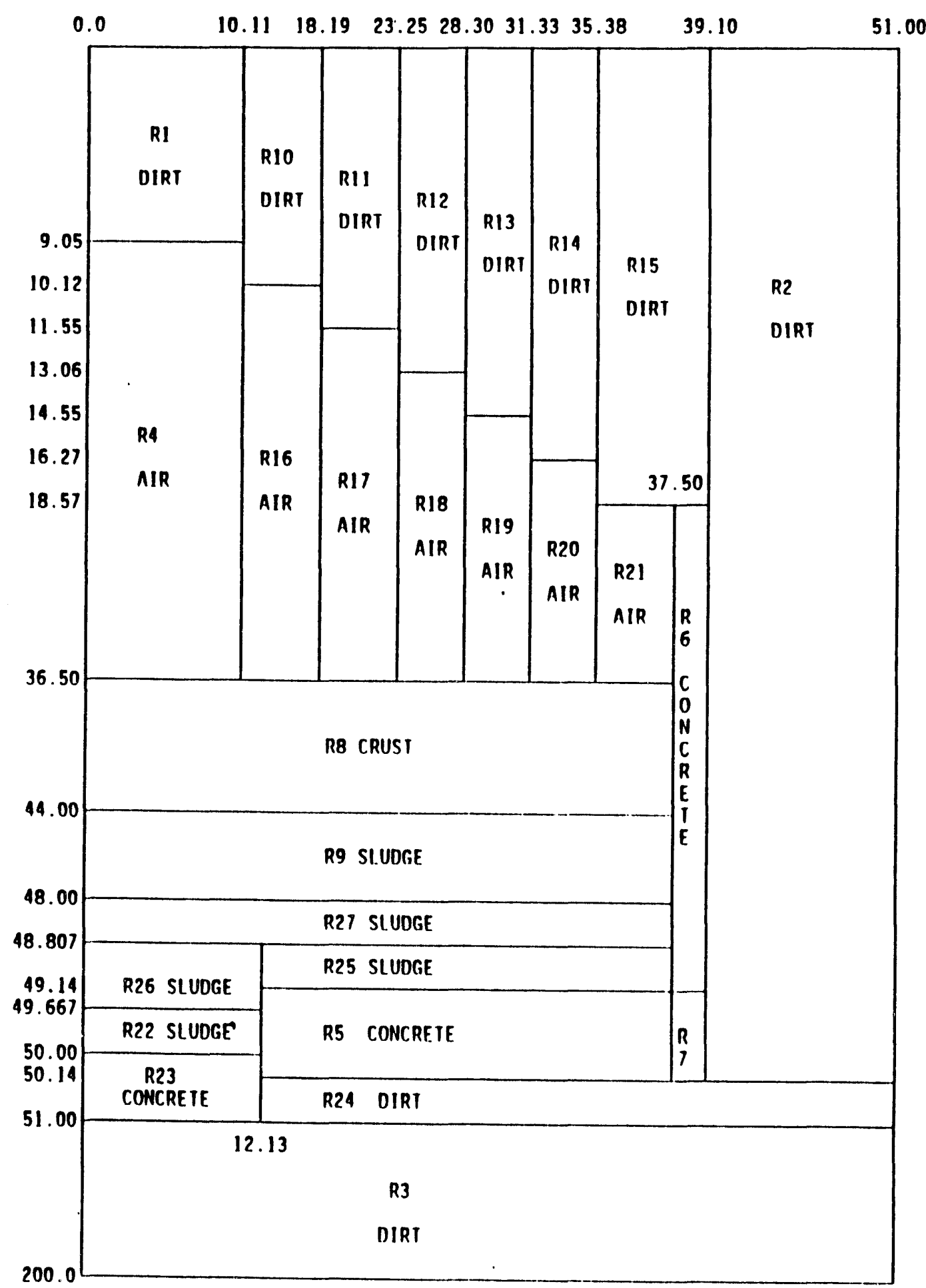




\section{WHC-EP-0638}

Figure A-12.

Options

maxpts $=2650$

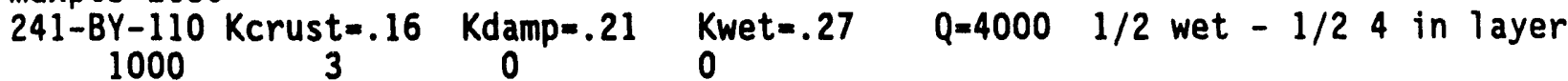
regions

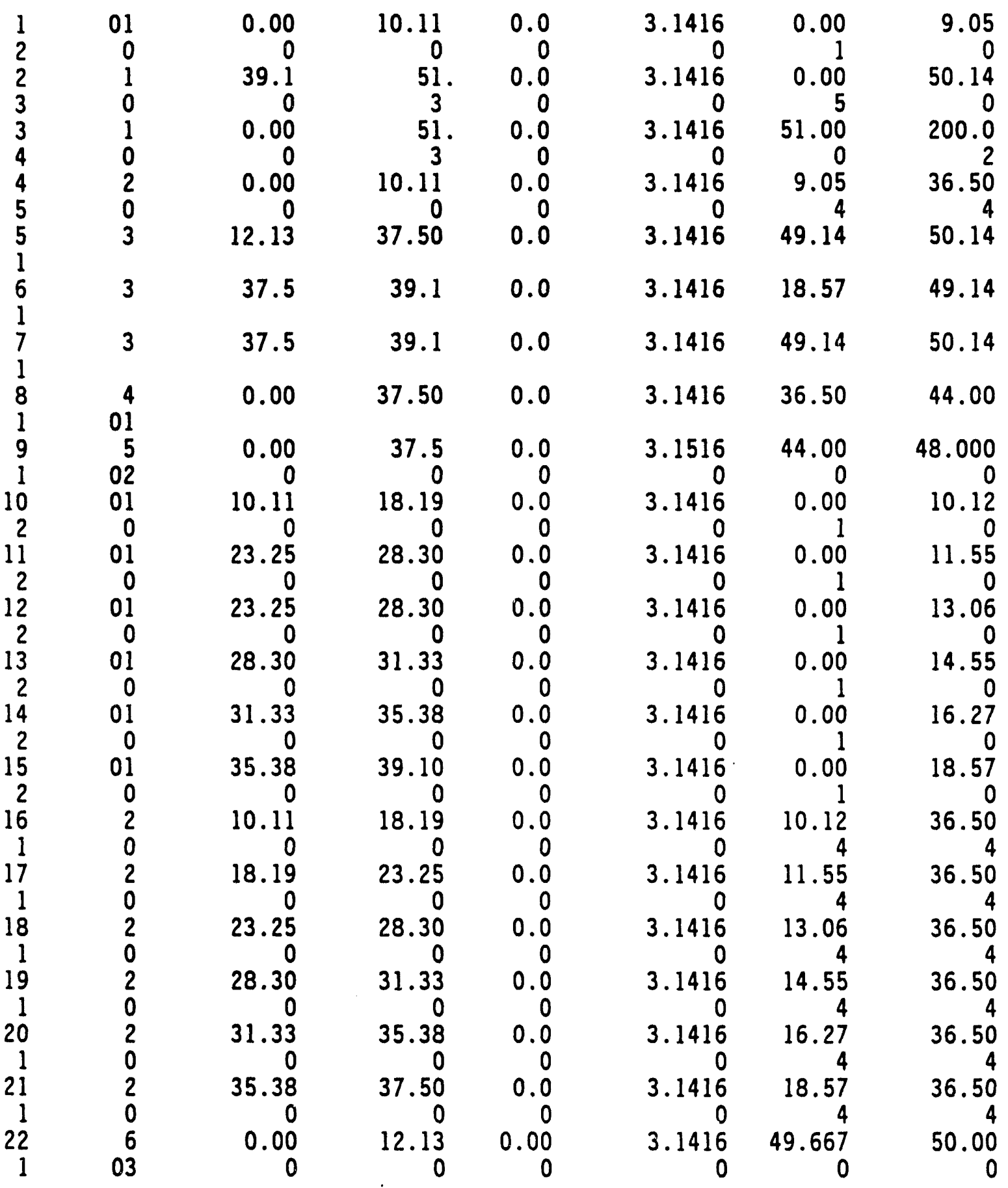


WHC-EP-0638

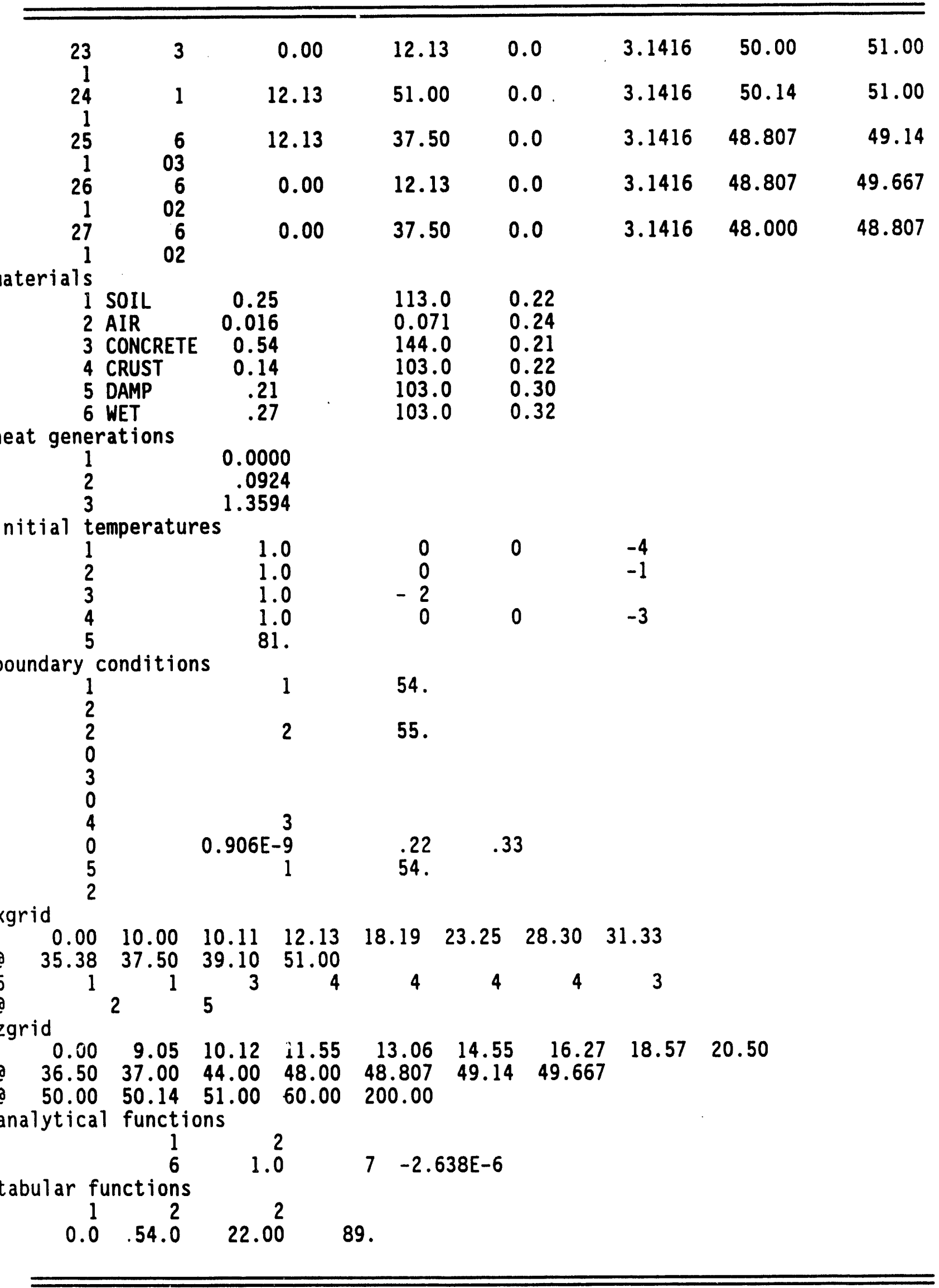


WHC-EP-0638

$\begin{array}{rrrrrrrr}2 & 2 & & & & \\ 39.1 & 134 . & 39.1 & 134 . & 51.0 & 90.0 & & \\ 3 & 2 & & & & & \\ 51.00 & 123 . & 200.0 & 55.0 & & & \\ 22.00 & 89.0 & 43.00 & 89.0 & 50.00 & 123.0 & 51.00 & 123.0 \\ \text { printout times } \\ \begin{array}{c}0.0 \\ \text { steady state } \\ 1\end{array}\end{array}$


This page intentionally left blank. 


\section{DISTRIBUTION}

\section{Number of Copies}

\section{OFFSITE}

12

U.S. Department of Energy

EM-35, Trevion II

Washington, D.C. 20585

John C. Tseng

1

U.S. Department of Energy

Savannah River Operations Office

P.O. Box A

Aiken, South Carolina 29808

Thomas C. Temple

1

Charles S. Abrams

1987 Virginia

Idaho Falls, ID 83404

1

David O. Campbell

102 Windham Road

Oak Ridge, TN 37830

1

Fred N. Carlson

6965 North 5th West

Idaho Falls, ID 83401

1

Donald T. Oakley

409 12th Street SW, Suite 310

Washington, DC 20024-2188

1

Arlin K. Postma

3640 Ballard Road

Dallis, Oregon 97338

1

William R. Prindle 1556 Crestline Drive

Santa Barbara, CA 93105 


\section{DISTRIBUTION (Continued)}

\section{Number of Copies}

\section{OFFSITE}

Alfred Schneider

5005 Hidden Branches Drive

Dunwoody, GA 30338

Air Products \& Chemicals, Inc. 7201 Hamilton Blvd

Allentown, PA 18195-1501

George E. Schmauch

1

Battelle Columbus Laboratories

505 King Avenue

Columbus, OH 43201-2693

James A. Gieseke

1

Brookhaven National Laboratory

Upton, NY 11973

Kamal K. Bandyopadhyay

1

Design Science, Inc.

163 Witherow Road

Sewickley, PA 15143

Gary Powers

1

Fauske and Associates. Inc. 16W070 W. 83rd St.

Burr Ridge, IL 60521

Hans K. Fauske

1

Florida State University

Department of Chemistry B-164

Tallahassee, FL 32306

Greg R. Choppin 


\section{DISTRIBUTION (Continued)}

Number of Copies

\section{OFFSITE}

1

Harvard University

295 Upland Avenue

Newton Highlands, MA 02161

Melvin W. First

1

Hazards Research Corporation

200 Valley Road, Suite 301

Mt. Arlington, NJ 07856

Chester Grelecki

1

Lawrence Livermore National Laboratory

P.O. Box 808, L-221

Livermore, CA 94550

Billy C. Hudson

Los Alamos National Laboratory

P.O. Box 1663

Los Alamos, NM 87545

Steve F. Agnew

Steve W. Eisenhawer

Thomas E. Larson

L. Harold Sullivan

MIT/Department of Nuclear Engineering

77 Massachusetts Ave.

Room 24-102

Cambridge, MA 02139

Mujid S. Kazimi 


\section{DISTRIBUTION (Continued)}

Number of Copies

\section{OFESITE}

1

3

Emory D. Collins

P.O. Box 2008

7930, MS-6385

Oak Ridge, TN 37831-6385

Charles W. Forsberg

P.O. Box 2008

MS-6495

Oak Ridge, TN 37831-6495

Thomas S. Kress

P.O. Box 2009

9108, MS-8088

Oak Ridge, TN 37831-8088

1

Rice University

5211 Paisley

Houston, TX 77096

Andrew S. Veletsos

1

Sandia National Laboratory

P.O. Box 5800

Albuquerque, NM 87185

Scott E. Slezak 


\section{DISTRIBUTION (Continued)}

\section{Number of Copies}

\section{OFFSITE}

3

Science Applications Intemational Corporation

12850 Middlebrook Road

Trevion I, Suite 300

Germantown, MD 20874

Attn: Ray S. Daniels (3)

1

State of Washington

Department of Ecology

P.O. Box 47600

Olympia, WA $98504-7600$

Michael T. Gordon

1

University of South Carolina

Department of Electrical and Computer Engineering

Swearingen Engineering Center

Columbia, SC 29208

Joseph S. Byrd

1

University of Washington

Center for Process Analytical Chemistry

Chemistry Department BG-10

Seattle, WA 98195

Bruce R. Kowalski

1 Vanderbilt University

P.O. Box 1596, Station B

Nashville, TN 37235

Frank L. Parker 


\section{DISTRIBUTION (Continued)}

ONSITE

9

U.S. Department of Energy. Richland Operations Office

R. F. Christensen (4)

R3-72

R. E. Gerton

R3-72

A. G. Krasopoulos

A4-81

Public Reading Room

H2-53

RL Docket File (2)

H5-36

8

Pacific Northwest Laboratory

R. T. Allemann

K7-15

S. A. Bryan

P7-25

B. M. Johnson

K1-78

M. A. Lilga

P8-38

R. D. Scheele

P7-25

G. F. Schiefelbein

P8-38

D. M. Strachan

K2-38

Hanford Technical Library

P8-55

44

Westinghouse Hanford Company

H. Babad

R2-78

J. B. Billetdeaux

R2-08

D. C. Board

S1-57

G. L. Borsheim

R2-11

R. J. Cash (2)

R2-78

M. D. Crippen

L5-31

G. M. Christensen

H4-21

D. R. Dickinson

L5-31

G. T. Dukelow

R2-78

C. J. Forbes

R1-08

J. C. Fulton

R2-31

J. M. Grigsby

H4-62

B. M. Hanlon

R1-80

H. D. Harmon

R2-52

J. M. Held

R3-09 


\section{DISTRIBUTION (Continued)}

\section{Number of Copies}

ONSITE

Westinghouse Hanford Company (continued)

M. N. Islam

R3-08

D. W. Jeppson

L5-31

N. W. Kirch

R2-11

W. L. Knecht

H0-34

C. A. Kuhlman

B3-30

M. Kummerer

H4-62

J. D. McCormack

L5-31

J. M. McLaren

H0-34

J. E. Meacham

R2-78

N. J. Milliken

H4-62

S. R. Moreno

B3-06

A. F. Noonan

R2-12

R. S. Popielarczyk

R1-30

D. A. Reynolds

R2-11

F. R. Reich

L5-63

C. P. Schroeder

L7-06

B. C. Simpson

R2-12

J. P. Summerhays

R2-85

H. Toffer

H0-38

W. T. Watson

H0-38

W. D. Winkelman

L5-55

D. D. Wodrich

H0-30

D. D. Wodrich

R2-85

W. F. Zuroff

R2-14

Central Files

L8-04

EDMC

H6-08

Information Release Administration

R1-05

TFIC

R1-20 
This page intentionally left blank. 

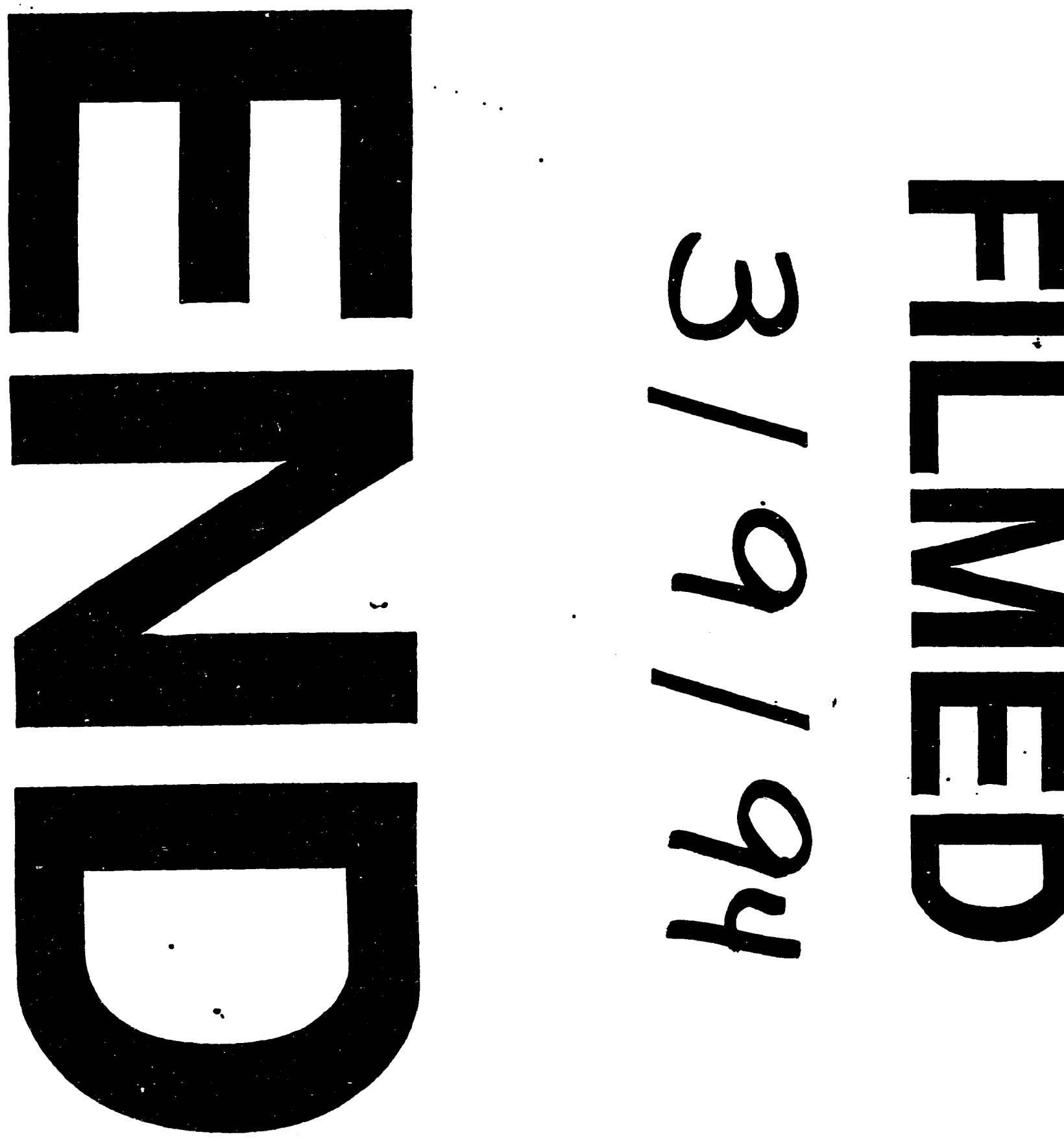

$\simeq 0$

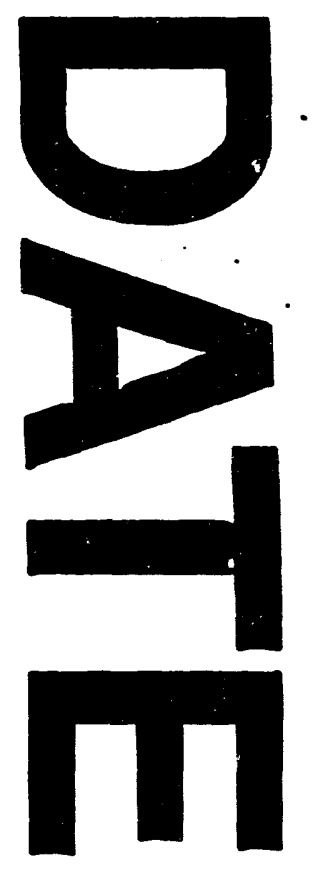




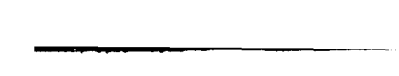

